\title{
Summary of Suspended-Solids Concentration Data, San Francisco Bay, California, Water Year 1998
}

By Paul A. Buchanan and Catherine A. Ruhl

U.S. GEOLOGICAL SURVEY

Open-File Report 00-88

Prepared in cooperation with the

SAN FRANCISCO REGIONAL WATER QUALITY CONTROL BOARD, and the U.S. ARMY CORPS OF ENGINEERS, SAN FRANCISCO DISTRICT

के 


\title{
U.S. DEPARTMENT OF THE INTERIOR \\ BRUCE BABBITT, Secretary
}

\author{
U.S. GEOLOGICAL SURVEY \\ Charles G. Groat, Director
}

The use of firm, trade, and brand names in this report is for identification purposes only and does not constitute endorsement by the U.S. Geological Survey

For additional information write to:

District Chief
U.S. Geological Survey
Placer Hall, Suite 2012
6000 J Street
Sacramento, CA 95819
Copies of this report can be purchased from:

\author{
U.S. Geological Survey \\ Information Services \\ Box 25286 \\ Federal Center \\ Denver, CO 80225
}




\section{CONTENTS}

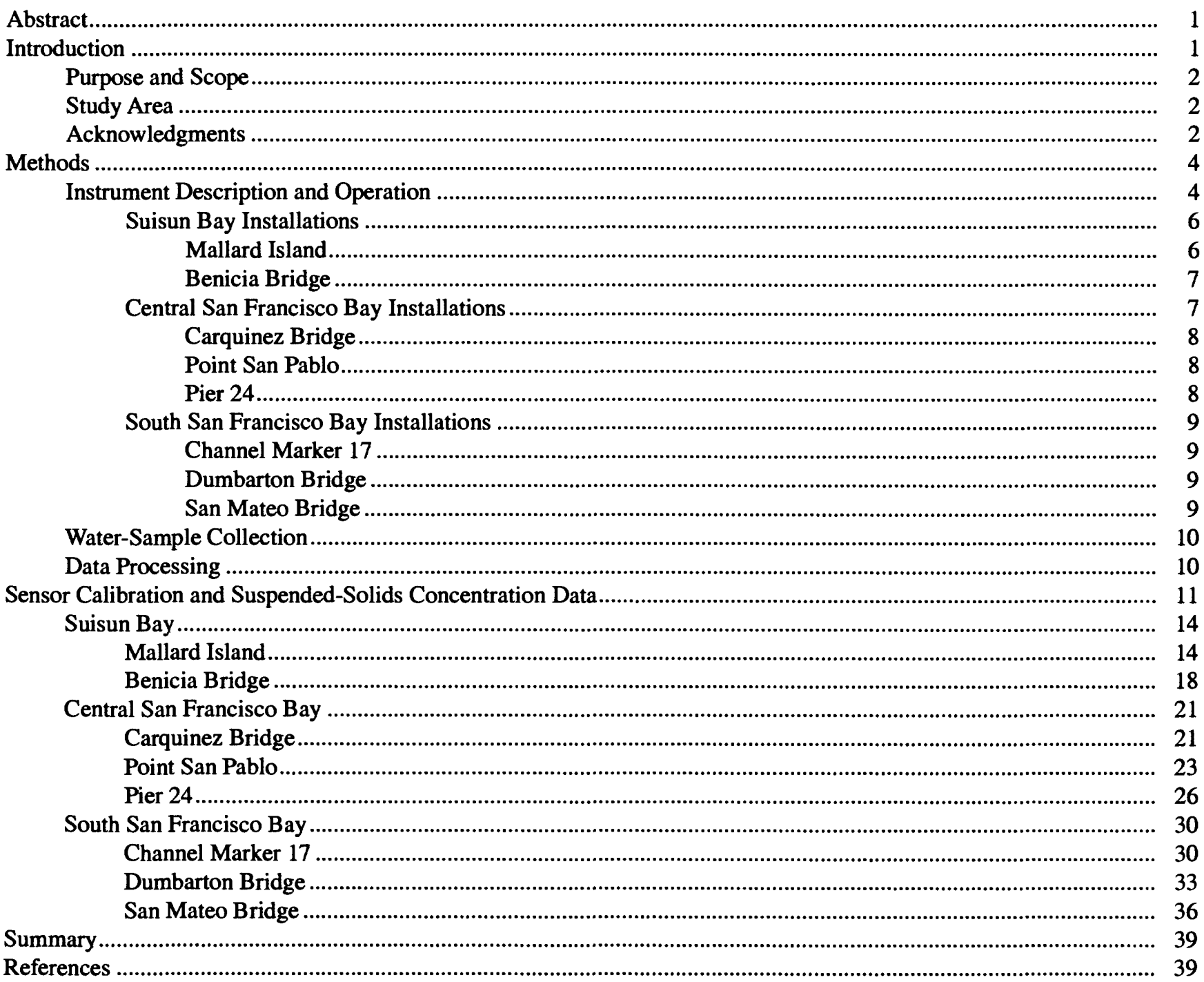

\section{FIGURES}

1. Map showing San Francisco Bay study area, California....................................................................................

2. Schematic of monitoring installation ..................................................................................................................

3-24. Graphs showing:

3. Raw and edited optical backscatterance data, mid-depth sensor, Point San Pablo, Central San Francisco

Bay, California, water year 1994

4. Calibration of near-surface optical backscatterance sensor during normal conditions,

October 1-January 31 and April 5-September 30, and during flood conditions, February 1-April 4 at

Mallard Island, Suisun Bay, California, water year 1998

5. Calibration of near-bottom optical backscatterance sensor during normal conditions, October 1-

January 31 and April 5-September 30, and during flood conditions, February 1-April 4 at Mallard Island, Suisun Bay, California, water year 1998. 
6. Time series of near-surface and near-bottom suspended-solids concentrations calculated from sensor readings at Mallard Island, Suisun Bay, California, water year 1998

7. Calibration of near-surface and near-bottom optical backscatterance sensors at Benicia Bridge,

Suisun Bay, California, water year 1998.

8. Time series of near-surface and near-bottom suspended-solids concentrations calculated from sensor readings at Benicia Bridge, Suisun Bay, California, water year 1998

9. Calibration of mid-depth and near-bottom optical backscatterance sensors at Carquinez Bridge, Central San Francisco Bay, California, water year 1998.

10. Time series of mid-depth and near-bottom suspended-solids concentrations calculated from sensor readings at Carquinez Bridge, Central San Francisco Bay, California, water year 1998

11. Calibration of mid-depth and near-bottom optical backscatterance sensors at Point San Pablo, Central San Francisco Bay, California, water year 1998.

12. Time series of mid-depth and near-bottom suspended-solids concentrations calculated from sensor readings at Point San Pablo, Central San Francisco Bay, California, water year 1998.

13. Calibration of mid-depth optical backscatterance sensors at Pier 24, Central San Francisco Bay, California, October 1-May 19 and May 20-September 30, water year 1998

14. Calibration of near-bottom optical backscatterance sensor at Pier 24, Central San Francisco Bay, California, water year 1998

15. Time series of mid-depth and near-bottom suspended-solids concentrations calculated from sensor readings at Pier 24, Central San Francisco Bay, California, water year 1998

16. Calibration of mid-depth optical backscatterance sensor at Channel Marker 17, South San Francisco Bay, California, water year 1998

17. Calibration of near-bottom optical backscatterance sensors at Channel Marker 17, South San Francisco Bay, California, October 1-July 29 and July 30-September 30, water year 1998

18. Time series of mid-depth and near-bottom suspended-solids concentrations calculated from sensor readings at Channel Marker 17, South San Francisco Bay, California, water year 1998

19. Calibration of mid-depth optical backscatterance sensor at Dumbarton Bridge, South San Francisco Bay, California, water year 1998

20. Calibration of near-bottom optical backscatterance sensors at Dumbarton Bridge, South San Francisco Bay, California, October 1-July 1 and July 1-September 30, water year 1998

21. Time series of mid-depth and near-bottom suspended-solids concentrations calculated from sensor readings at Dumbarton Bridge, South San Francisco Bay, California, water year 1998

22. Calibration of mid-depth optical backscatterance sensor at San Mateo Bridge, South San Francisco Bay, California, water year 1998

23. Calibration of near-bottom optical backscatterance sensors at San Mateo Bridge, South San Francisco Bay, California, October 1-April 8 and April 9-September 30, water year 1998

24. Time series of mid-depth and near-bottom suspended-solids concentrations calculated from sensor readings at San Mateo Bridge, South San Francisco Bay, California, water year 1998

\section{TABLES}

1. Statistical summary of suspended-solids concentration data, Suisun Bay and Central and South San Francisco Bays, California, water year 1998

2. Percentage of valid data collected by optical backscatterance sensors, Suisun Bay and Central and South San Francisco Bays, California, water year 1998 


\section{CONVERSION FACTORS, VERTICAL DATUM, ABBREVIATIONS, AND ACRONYMS}

\begin{tabular}{rcl}
\hline \multicolumn{1}{c}{ Multiply } & \multicolumn{1}{c}{ By } & \multicolumn{1}{c}{ To obtain } \\
\hline inch (in.) & 25.4 & millimeter \\
foot (ft) & .3048 & meter \\
mile (mi) & 1.609 & kilometer \\
foot per second (ft/s) & .3048 & meter per second \\
pound, avoirdupois (lb) & .4536 & kilogram \\
\hline
\end{tabular}

Temperature in degrees Celsius $\left({ }^{\circ} \mathrm{C}\right)$ may be converted to degrees Fahrenheit $\left({ }^{\circ} \mathrm{F}\right)$ as follows:

$$
{ }^{\circ} \mathrm{F}=\left(1.8 \times{ }^{\circ} \mathrm{C}\right)+32
$$

\section{Vertical Datum}

Sea level: In this report, "sea level" refers to the National Geodetic Vertical Datum of 1929 (NGVD of 1929)-a geodetic datum derived from a general adjustment of the first-order level nets of both the United States and Canada, formerly called Sea Level Datum of 1929.

Mean lower low water (MLLW): The average of the lower low water height of each tidal day observed over the National Tidal Datum Epoch. The National Tidal Datum Epoch is the specific 19-year period (19601978 for values given in this report) adopted by the National Ocean Service as the official time segment over which tide observations are taken and reduced to obtain mean values.

\section{Abbreviations}

$\begin{array}{ll}\text { Ah } & \text { ampere hour } \\ \mathrm{mg} / \mathrm{L} & \text { milligram per liter } \\ \mathrm{mV} & \text { millivolt } \\ \mathrm{V} & \text { volt }\end{array}$

\section{Acronyms}

AC alternating current

ADAPS automated data-processing system

DC direct current

DWR California Department of Water Resources

NOAA National Oceanic and Atmospheric Administration

NTU Nephelometric Turbidity Units

PVC polyvinyl chloride

USGS U.S. Geological Survey 


\title{
Summary of Suspended-Solids Concentration Data, San Francisco Bay, California, Water Year 1998
}

\author{
By Paul A. Buchanan and Catherine A. Ruhl
}

\section{ABSTRACT}

Suspended-solids concentration data were collected in San Francisco Bay during water year 1998 (October 1, 1997-September 30, 1998). Optical backscatterance sensors and water samples were used to monitor suspended solids at two sites in Suisun Bay, three sites in Central San Francisco Bay, and three sites in South San Francisco Bay. Sensors were positioned at two depths at most sites. Water samples were collected periodically and were analyzed for concentrations of suspended solids. The results of the analyses were used to calibrate the electrical output of the optical backscatterance sensors. This report presents the data-collection methods used and summarizes the suspended-solids concentration data collected from October 1997 through September 1998. Calibration plots and plots of edited data for each sensor also are presented.

\section{INTRODUCTION}

Sediments are an important component of the San Francisco Bay estuarine system. Bottom sediments provide habitat for benthic organisms and are a reservoir of nutrients that contribute to the maintenance of estuarine productivity (Hammond and others, 1985). Potentially toxic substances, such as metals and pesticides, adsorb to sediment particles (Kuwabara and others, 1989; Domagalski and Kuivila, 1993; Flegal and others, 1996). Benthic organisms can ingest these substances and introduce them into the food web (Luoma and others, 1985; Brown and Luoma, 1995; Luoma, 1996).

The transport and fate of suspended sediments are important factors in determining the transport and fate of constituents adsorbed on the sediments. In Suisun Bay, the maximum concentration of suspended sediment usually marks the position of the turbidity maximum, which is a crucial ecological region in which suspended sediments, nutrients, phytoplankton, zooplankton, larvae, and juvenile fish accumulate (Peterson and others, 1975; Arthur and Ball, 1979; Kimmerer, 1992; Jassby and Powell, 1994; Schoellhamer and Burau, 1998).

Suspended sediments limit the availability of light in San Francisco Bay, which, in turn, limits photosynthesis and primary photosynthetic carbon production (Cole and Cloern, 1987; Cloern, 1987, 1996). Suspended sediments also deposit in ports and shipping channels, which then must be dredged to maintain navigation (U.S. Environmental Protection Agency, 1992). The U.S. Geological Survey (USGS), in cooperation with the San Francisco Regional Water Quality Control Board and the U.S. Army Corps of Engineers, is studying the factors that affect suspended-solids concentrations in San Francisco Bay. 


\section{Purpose and Scope}

This report summarizes suspended-solids concentration data collected by the USGS in San Francisco Bay during water year 1998 (October 1, 1997-September 30, 1998). Suspended-solids concentrations were monitored at two sites in Suisun Bay, three sites in Central San Francisco Bay, and three sites in South San Francisco Bay.

This report is the latest in a series summarizing suspended-solids concentration data collected in San Francisco Bay beginning in water year 1992 (Buchanan and Schoellhamer, 1995, 1996, 1998, 1999; Buchanan and others, 1996). These data have been used to study suspended-solids flux at Mallard Island in Suisun Bay (Tobin and others, 1995), to study the factors that affect suspendedsolids concentration in South San Francisco Bay (Schoellhamer,1996), to study suspended-solids flux in South San Francisco Bay (Lacy and others, 1996), to estimate the temporal variation of trace elements (Schoellhamer, 1997), to determine an optimum sampling strategy for sedimentassociated pesticides in Suisun Bay (Jennings and others, 1997), to compare suspended-solids concentrations in the shallow waters of Suisun Bay and at Mallard Island (Schoellhamer and Burau, 1998; Ruhl and Schoellhamer, 1999), and to study sediment inflow from the Sacramento-San Joaquin River Delta to Suisun Bay at Mallard Island (Oltmann and others, 1999). Suspended-solids concentration data for water years 1992-98 are available from the USGS California District Office.

\section{Study Area}

San Francisco Bay (fig. 1) is comprised of several major subembayments: Suisun Bay, San Pablo Bay, Central San Francisco Bay (Central Bay), and South San Francisco Bay (South Bay). In San Francisco Bay, tides are semidiurnal (two high and two low tides per day) with a range from about 5.5 feet (ft) in Suisun Bay, to $6.5 \mathrm{ft}$ at the Golden Gate and Central Bay, to about $10 \mathrm{ft}$ in South Bay. The tides also have a 14-day spring neap cycle. Typical tidal currents range from 0.6 feet per second (ft/s) in shallow water to more than $3 \mathrm{ft} / \mathrm{s}$ in deep channels (Smith, 1987; Cheng and Gartner, 1984). Winds typically are strongest during the summer when there is an afternoon onshore sea breeze. Most precipitation occurs from late autumn to early spring, and freshwater discharge into the Bay is greatest in the spring, as a result of runoff from snowmelt. About 90 percent of the discharge into the Bay is from the Sacramento-San Joaquin River Delta, which drains the Central Valley of California (Smith, 1987).

Discharge from the Delta contains 83-86 percent of the fluvial sediments that enter the Bay (Porterfield, 1980). During wet winters, turbid plumes of water from the Delta have extended into South Bay (Carlson and McCulloch, 1974). The bottom sediments in South Bay and in the shallow (about $12 \mathrm{ft}$ or less) water of Central, San Pablo, and Suisun bays are composed mostly of silts and clays. Silts and sands are present in the deeper parts of Central, San Pablo, and Suisun bays and in Carquinez Strait (Conomos and Peterson, 1977). Large tidal velocities, spring tides, and wind waves in shallow water are all capable of resuspending bottom sediments (Powell and others, 1989; Schoellhamer, 1996).

\section{Acknowledgments}

The authors gratefully acknowledge the U.S. Coast Guard, California Department of Transportation, California Department of Water Resources (DWR), the San Francisco Port Authority, and the PakTank Corporation for their permission and assistance in establishing the monitoring sites used in this study. 


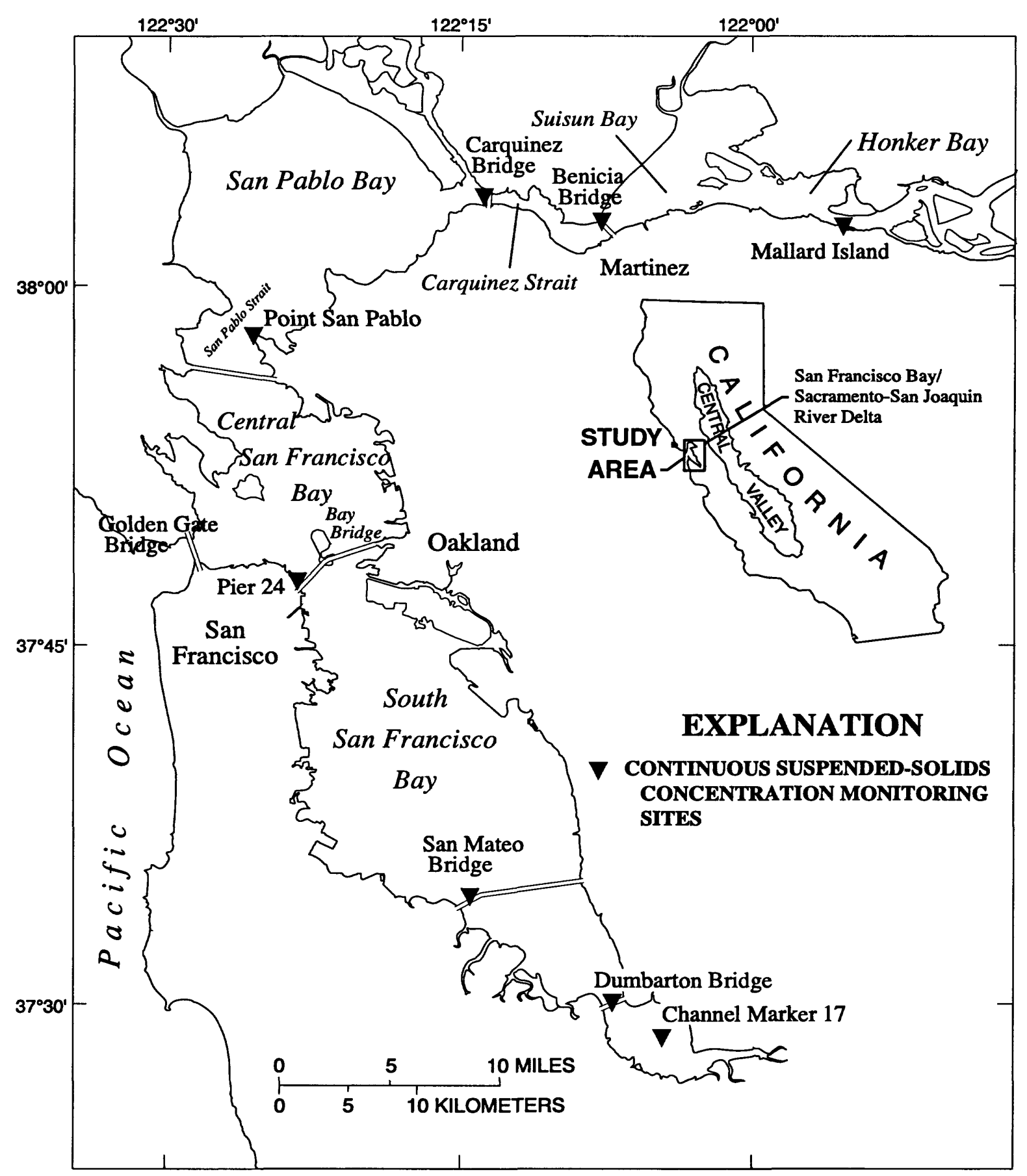

Figure 1. San Francisco Bay study area, California. 


\section{METHODS}

\section{Instrument Description and Operation}

Three different types of optical backscatterance sensors were used to monitor concentrations of suspended solids during water year 1998. The first type of sensor is manufactured by D \& A Instrument Company and is a cylinder approximately 7 inches (in.) long and 1 in. in diameter with an optical window at one end, a cable connection at the other end, and an encased circuit board (Downing and others, 1981; Downing, 1983). A high-intensity infrared emitting diode produces a beam through the optical window that is scattered, or reflected, by particles that are between about 0.2-12 in. in front of the window. A detector (four photodiodes) receives backscatter from a field of $140-165^{\circ}$ (D \& A Instrument Company, 1991), which is converted to a voltage output and recorded on a separate data logger. The second type of sensor, manufactured by BTG, is self-cleaning and similar in size and function to the other optical sensors used in the study, but each self-cleaning probe has a separate electronic unit that sets the resolution and maximum reading, expressed in Nephelometric Turbidity Units (NTU). The voltage output from the electronic unit is recorded on a separate data logger. The third type of sensor, manufactured by Hydrolab, is part of a multiprobe that also measures specific conductance, temperature, and depth. The Hydrolab optical backscatterance sensor measures the intensity of light scattered at $90^{\circ}$ from two light-emitting diodes and is expressed in NTU. The multiprobe (or sonde) is self contained with its own power source and data logger. The voltage output for all three types of sensors is proportional to the concentration of suspended solids in the water column at the depth of the sensor. Suspended-solids concentrations calculated from the output of side-by-side sensors with and without the self-cleaning function (BTG and D \& A Instrument Co.) are virtually identical (Buchanan and Schoellhamer, 1998, fig. 4). Calibration of the sensor voltage output to concentrations of suspended solids will vary according to the size and optical properties of the suspended solids; therefore, the sensors must be calibrated from samples collected in the field or a laboratory using suspended material from the field (Levesque and Schoellhamer, 1995).

The optical sensors were positioned in the water column using polyvinyl chloride (PVC) pipe carriages that were coated with an antifoulant paint to impede biological growth. These carriages were designed to align with the direction of flow and to ride along a stainless steel, or Kevlar-reinforced nylon, suspension line attached to an anchor weight, which allowed the sensors to be easily raised and lowered for servicing (fig. 2). The plane of the optical window was positioned parallel to the direction of flow and as the carriage and sensor moved with the changing direction of flow, the plane of the window retained its position, relative to the direction of flow.

Data acquisition, data storage, and sensor timing were controlled by an electronic data logger (either separate or internal, as in the case of the sonde). The logger was programmed to power the optical sensor every 15 minutes, collect data each second for 1 minute, and then average and store the output voltage for that 1-minute period. Power was supplied by 12-volt (V) direct current (DC), 12-ampere hour (Ah), gel-cell batteries, except for the sonde, which used 8 size-C alkaline batteries.

Biological growth interferes with the collection of accurate optical backscatterance data. Self-cleaning optical sensors with wipers were deployed at four sites during water year 1994 to help alleviate the problem of fouling. Because the self-cleaning sensor requires $95-130-\mathrm{V}$ 


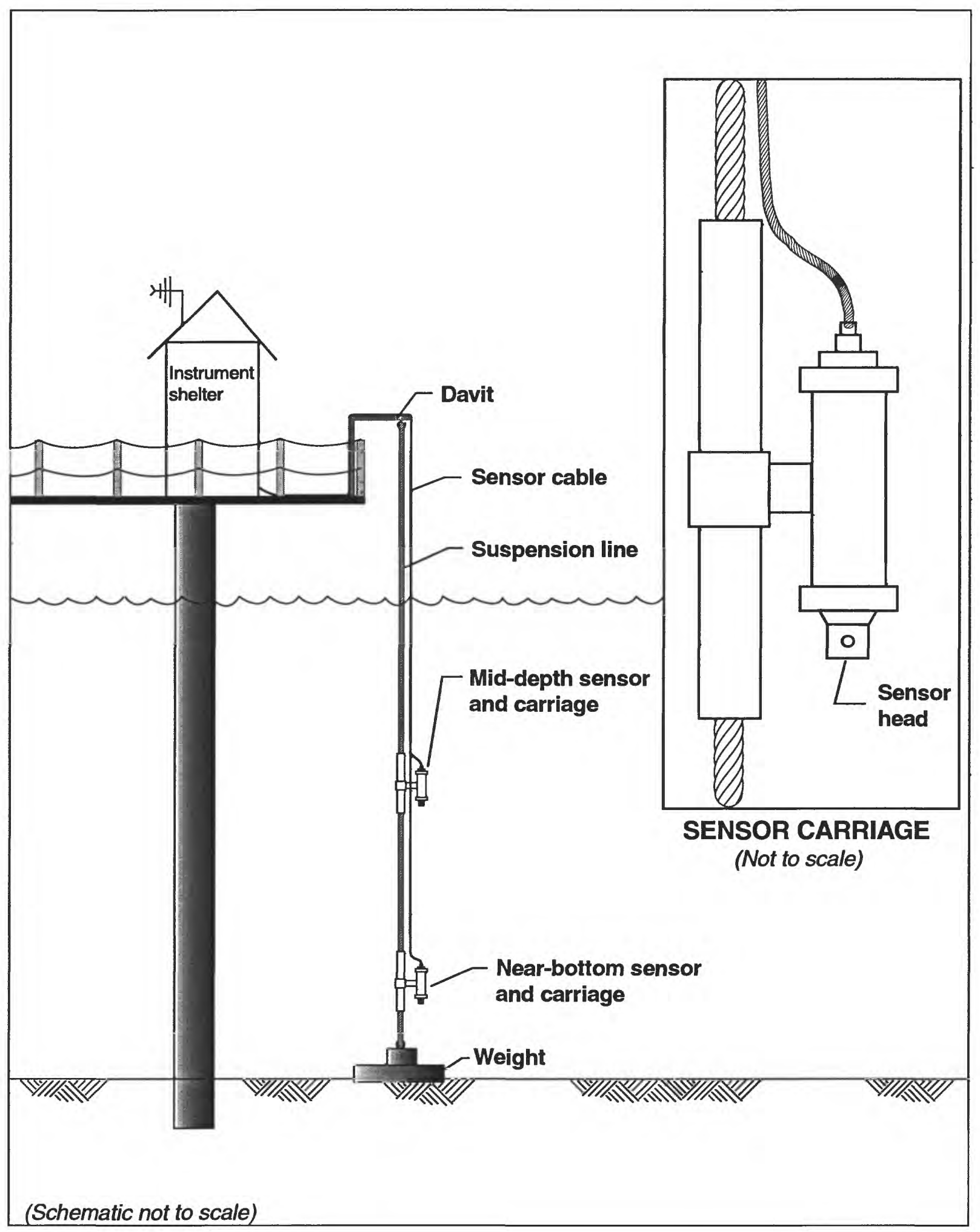

Figure 2. Monitoring installation. 
alternating current $(\mathrm{AC})$, installation was limited to sites with $\mathrm{AC}$ power. The self-cleaning probes and electronic units were installed at two sites in Suisun Bay and two sites in South Bay. Fouling in Suisun Bay was minor compared with that in South and Central bays, and the self-cleaning probes were effective in keeping the optical ports clean. However, fouling at the two sites in South Bay during the summer was so extreme that the self-cleaning probes often were rendered ineffective by biological growth on the carriage and wiper mechanism. During water year 1995, all self-cleaning probes deployed in South Bay failed because of salt crystals forming on an O-ring, which resulted in water leakage into the units. To address the leakage problem, the design was modified by the manufacturer. In water year 1996, an updated version of the self-cleaning probe was deployed at the Dumbarton Bridge site in South Bay, but it failed within the first month of operation. Thereafter, the self-cleaning probes were used only at the less saline Mallard Island site in Suisun Bay.

Optical sensors without self-cleaning wipers required frequent cleaning but, because of the difficulty in servicing some of the monitoring stations, cleaning was done every 1-5 (usually 3) weeks.

Fouling generally was greatest on the sensor closest to the water surface. However, fouling at shallower sites was about equal on both sensors where the upper sensor was set $10 \mathrm{ft}$ above the lower sensor. Fouling would begin to affect sensor output from 2 days to several weeks after cleaning, depending on the level of biological activity in the Bay. Generally, biological fouling was greatest during the spring and summer.

On-site checks of sensor accuracy were performed using turbidity solutions prepared from a 4,000-NTU formazin standard. Formazin is an aqueous suspension of an insoluble polymer and is specified as the primary turbidity standard by the American Society for Testing and Materials. The turbidity solutions are prepared by diluting a 4,000-NTU stock standard with high-purity water in a clean, white, sealable bucket. Prepared solutions ranged from 50 to 200 NTU. At the field site, the cleaned sensors are immersed in the solution and the voltage output is recorded on the station log. Monitoring a period of sensor performance in a known standard aids in identifying output drift or sensor malfunction.

\section{Suisun Bay Installations}

Suspended-solids concentration data were collected at two sites in Suisun Bay: Mallard Island and Benicia Bridge (fig. 1). Monitoring equipment was installed at the Mallard Island site during water year 1994, and the Benicia Bridge site was established during water year 1996 . The monitoring site at the Martinez Marina fishing pier was discontinued in water year 1996 because the data from the Benicia Bridge were considered more representative of suspended-solids concentration in the Carquinez Strait area of Suisun Bay (Buchanan and Schoellhamer, 1998).

\section{Mallard Island}

Self-cleaning optical sensors were installed at the DWR Mallard Island Compliance Monitoring Station on February 8, 1994. This site is about 5 miles (mi) downstream from the confluence of the Sacramento and San Joaquin Rivers and is at the north shore of Mallard Island near the eastern boundary of Honker Bay, an embayment of Suisun Bay (fig. 1). The station was constructed in the early 1980s by DWR on Pacific Gas and Electric Company property, and waterquality data were first recorded at the station in January 1984. A 1/4-mi wooden walkway crosses the sometimes submerged reed beds of Mallard Island and connects the concrete block instrument shelter to the levee road. 
Sensors were positioned at near-bottom ( $5 \mathrm{ft}$ above the bottom) and near-surface ( $3.3 \mathrm{ft}$ below the surface) depths to coincide with DWR near-bottom depth electrical conductance and temperature sensors and the near-surface pump intake. The pump intake was attached to a float that is housed inside a 12-in. PVC pipe, and the intake drew water from about $3 \mathrm{ft}$ below the surface. DWR near-surface parameters were measured by sensors that are submerged in flowthrough chambers inside the instrument shelter. This configuration saved the cost of installing duplicate sets of sensors and enabled the USGS to use DWR data for parameters other than turbidity, such as stage, $\mathrm{pH}$, chlorophyll concentration, and meteorology. Mean lower low water depth at this site was about $25 \mathrm{ft}$.

Data storage was controlled by a data logger connected to a cellular phone and modem. AC power operated both optical sensors and charged a 12-V, 12-Ah battery that powered the data logger and modem. The data logger and peripheral equipment are housed in the instrument shelter. The sensors were suspended from a galvanized support stand that was attached to a metal railing on the station's northwest concrete deck. The support stand had two stainless-steel lines attached to separate concrete weights; one line for the near-bottom sensor and one line for the near-surface sensor. The near-bottom sensor was attached to a PVC carriage suspended on the stainless-steel line by a nylon rope at the specified depth. The near-surface sensor was attached to a PVC carriage that was built onto a float. This float assembly moved up and down the suspension line during tidal cycles, which maintained the near-surface sensor at the same depth as the DWR pump intake. A pressure transducer was positioned on the float assembly at the same level as the sensor and provided data to verify the depth of the near-surface sensor. To prevent sensor cables from being snagged by debris, a counterweight was installed to keep slack cables out of the water.

\section{Benicia Bridge}

Suspended-solids concentration monitoring equipment was installed March 15, 1996, at the Benicia Bridge. This site is pn Pier 7 of the Benicia Bridge, north of the main ship channel (fig. 1). The National Oceanic and Atmospheric Administration (NOAA) operates salinity sensors and an acoustic Doppler current profiler near this site. Optical sensors without the selfcleaning function were deployed at near-bottom and near-surface depths $(25 \mathrm{ft}$ and $74 \mathrm{ft}$, respectively, above the bottom) to coincide with the elevations of the NOAA sensors. The average mean lower low water depths near the pier were about $60 \mathrm{ft}$; however, the depths immediately surrounding the pier were about $20 \mathrm{ft}$ greater. The near-bottom sensor was set $25 \mathrm{ft}$ above the bottom to collect data representative of the average mean lower low water depth. The sensors were suspended between the concrete pier superstructure and the fender boards, which were approximately $1 \mathrm{ft}$ apart. PVC carriages attached to 1/4-in. stainless-steel line were anchored to a 125-pound (lb) weight and used to suspend the sensors at the desired depth. AC power charged a 12-V, 12-Ah battery that powered the data logger and sensors. The data logger and peripheral equipment were housed in a $3 \times 2 \times 1-\mathrm{ft}$ plastic weather-proof shelter mounted on the pier.

\section{Central San Francisco Bay Installations}

Suspended-solids concentration data were collected at three sites in Central Bay: Carquinez Bridge, Point San Pablo, and Pier 24 (fig. 1). The monitoring station at the south 
tower of the Golden Gate Bridge was discontinued at the beginning of water year 1998 because of the difficulty in collecting continuous data.

\section{Carquinez Bridge}

Suspended-solids monitoring equipment was installed April 21, 1998, at the Carquinez Bridge. This site is on the north side of the center pier structure of the Carquinez Bridge (fig. 1). Sondes with optical, specific conductance, and temperature sensors were deployed at nearbottom and middle depths ( $5 \mathrm{ft}$ and $48 \mathrm{ft}$, respectively, from the bottom). Mean lower low water depth at this site was about $88 \mathrm{ft}$. The sensors were suspended between the concrete pier superstructure and the fender boards, which were approximately $1 \mathrm{ft}$ apart. PVC carriages attached to 1/4-in. stainless-steel line were anchored to a $250-1 b$ weight and used to suspend the sensors at the desired depth. Sensor timing and storage were controlled by an internal data logger. Power was supplied by 8 size-C alkaline batteries that were replaced during site visits. No instrument shelter was needed at this site.

\section{Point San Pablo}

The USGS maintains a monitoring site at San Pablo Strait on the northern end of the Richmond Terminal No. 4 pier on the western side of Point San Pablo (fig. 1). The USGS assumed operation of this site from DWR in October 1989. Data collected prior to October 1, 1989, can be obtained from DWR.

Optical sensors were installed at Point San Pablo on December 1, 1992, and were positioned at near-bottom and middle depths ( $3 \mathrm{ft}$ and $13 \mathrm{ft}$, respectively, from the bottom). Mean lower low water depth at this site was about $26 \mathrm{ft}$. Sensor timing and storage were controlled by a data logger that was connected to a phone line and modem. Specific conductance and temperature data (cooperatively funded by DWR and the USGS) were collected at near-bottom and near-surface depths in the water column (near-bottom and near-surface depths were sampled to define the vertical stratification). PVC carriages attached to 1/4-in. stainless-steel line were anchored to a 125-lb weight and were used to suspend the sensors at the desired depth. Water level was recorded using a float-driven incremental encoder that was wired into the data logger; outside water levels were read during site visits using a wire-weight gage. AC power charged a 12-V, 60-Ah battery that powered the data logger and sensors. The data logger and peripheral equipment were housed in a $5 \times 8 \times 8-\mathrm{ft}$ wooden shelter.

\section{Pier 24}

The monitoring station at Pier 24 is on the western end of the San Francisco-Oakland Bay Bridge (fig. 1). The USGS assumed operation of this station from DWR in October 1989. Data collected prior to October 1, 1989, can be obtained from DWR.

Optical sensors were installed at the Pier 24 site on May 25, 1993, and were positioned at near-bottom and middle depths ( $3 \mathrm{ft}$ and $23 \mathrm{ft}$, respectively, above the bottom). Mean lower low water depth at this site was about $41 \mathrm{ft}$. As at the Point San Pablo station, specific conductance and temperature data (cooperatively funded by DWR and the USGS) were collected at nearbottom and near-surface depths in the water column. PVC carriages attached to 1/4-in. stainlesssteel line were anchored to a 125-lb weight and used to suspend the sensors at the desired depth. 
Sensor timing and storage were controlled by a data logger connected to a cellular phone and modem. AC power charged two 12-V, 12-Ah batteries that powered the instrumentation. The data logger and peripheral equipment were housed in a corrugated steel shelter.

\section{South San Francisco Bay Installations}

Suspended-solids concentration data were collected at three sites in South Bay (fig. 1). Monitoring sites were installed during water year 1992 at two sites in South Bay: Channel Marker 17 and San Mateo Bridge. The Dumbarton Bridge site was installed during water year 1993.

\section{Channel Marker 17}

The southernmost monitoring site in South Bay is at the Coast Guard Channel Marker 17 (fig. 1). Instrumentation was installed on February 26, 1992, and the optical sensors were positioned at near-bottom and middle depths ( $3 \mathrm{ft}$ and $13 \mathrm{ft}$, respectively, from the bottom). Mean lower low water depth at this site was about $25 \mathrm{ft}$. Sensor cables were protected by a 10-ft PVC pipe suspended from the channel marker platform. PVC carriages attached to 1/4-in. Kevlar-reinforced nylon line were anchored to a 100-lb weight and used to suspend the sensors at the desired depth. The data logger and $12-\mathrm{V}, 12$-Ah batteries were housed in a $2 \times 2 \times 1-\mathrm{ft}$ plastic weather-proof shelter mounted on the channel marker platform.

\section{Dumbarton Bridge}

Suspended-solids concentration monitoring equipment was installed on October 21, 1992, at Pier 23 of the Dumbarton Bridge on the west side of the ship channel (fig. 1). Optical sensors were deployed at near-bottom and middle depths ( $4 \mathrm{ft}$ and $23 \mathrm{ft}$, respectively, above the bottom). Mean lower low water depth was about $45 \mathrm{ft}$. The sensors were suspended between the concrete pier superstructure and its surrounding protective fender boards; a space approximately $3 \mathrm{ft}$ wide. PVC carriages attached to 1/4-in. stainless-steel line were anchored to a 125-lb weight and suspended the sensors at the desired depth. AC power charged a 12-V, 12-Ah battery that powered the instrumentation. The data logger and peripheral equipment were housed in a $3 \times 2 \times 1-\mathrm{ft}$ plastic weather-proof shelter mounted on the pier.

\section{San Mateo Bridge}

The monitoring site on the San Mateo Bridge is at Pier 20 on the east side of the ship channel (fig. 1). This station originally was operated by DWR, but the USGS assumed operations in October 1989. Data collected prior to October 1, 1989, can be obtained from DWR.

The optical sensors were installed on December 23, 1991, and were positioned at near-bottom and middle depths ( $8 \mathrm{ft}$ and $29 \mathrm{ft}$, respectively, above the bottom). Mean lower low water depth at this site was about $48 \mathrm{ft}$. The sensors were deployed between the pier and a protective fender structure, and flow past the sensors was affected, to some degree, by the pilings and the concrete superstructure. PVC carriages attached to $1 / 4$-in. stainless-steel line were anchored to a $200-\mathrm{lb}$ 
weight and suspended the sensors at the desired depth. A data logger was used to control sensor timing, data storage, and retrieval. In addition to suspended-solids concentrations, specific conductance and temperature (cooperatively funded by DWR and the USGS) were monitored at near-bottom and near-surface depths. AC power charged a $12-\mathrm{V}, 60-\mathrm{Ah}$ battery that powered the data logger and sensors. The data logger and peripheral equipment were housed in an $8 \times 6 \times 8-\mathrm{ft}$ wooden shelter on the pier.

\section{Water-Sample Collection}

Water samples used to calibrate optical sensors were collected using a horizontally positioned Van Dorn sampler before and after the sensors were cleaned. The Van Dorn sampler is a plastic tube with rubber stoppers at each end that snap shut when triggered by a small weight that is dropped down a suspension cable. The Van Dorn sampler was lowered to the depth of the sensor by a reel and crane assembly and triggered while the sensor was collecting data. Then, the water sample was removed from the sampler, marked for identification, and placed in a cooler and chilled to limit biological growth. The suspended-solids concentration of water samples collected with a Van Dorn sampler and a P-72 point sampler, which were used until water year 1994, were compared and found to be virtually identical (Buchanan and others, 1996, fig. 2).

Samples were sent to the USGS Sediment Laboratory in Salinas, California, for analysis to determine suspended-solids concentration. Suspended solids include all particles in the sample; the suspended sediment (material that settles to the bottom of the sample bottle), and buoyant particles that do not settle. Each sample was filtered through a 0.45 -micrometer membrane filter, the filter was rinsed to remove salts, and the insoluble material was dried at $103^{\circ} \mathrm{C}$ and weighed (Fishman and Friedman, 1989). The difference between suspended-solids concentration and suspended-sediment concentration for San Francisco Bay water probably is small.

\section{Data Processing}

Data loggers stored the voltage outputs from the optical sensors at 15-minute intervals. Recorded data were downloaded from the data logger onto a storage module during site visits. Raw data from the storage modules were loaded into the USGS automated data-processing system (ADAPS).

The time-series data were retrieved from ADAPS and edited using MATLAB software to remove invalid data. Invalid data included rapidly increasing voltage outputs and unusually high voltage outputs of short duration. As biological growth accumulated on the optical sensors, the voltage output of the sensors increased. An example time series of raw and edited optical backscatterance data from water year 1994 is presented in figure 3. After the sensors were cleaned, sensor output immediately decreased (fig. 3, April 19, June 8, and June 28). Efforts to correct the invalid data proved to be unsuccessful because the desired signal was sometimes highly variable. Thus, data collected during the period prior to sensor cleaning often were unusable and were removed from the record (fig. 3). Spikes in the data, which are anomalously high voltages probably caused by debris temporarily wrapped around the sensor or by large marine organisms (fish, crabs) on or near the sensor, also were removed from the raw data record (fig. 3). Sometimes, incomplete cleaning of a sensor would cause a small constant shift in sensor output that could be corrected using water-sample data. 

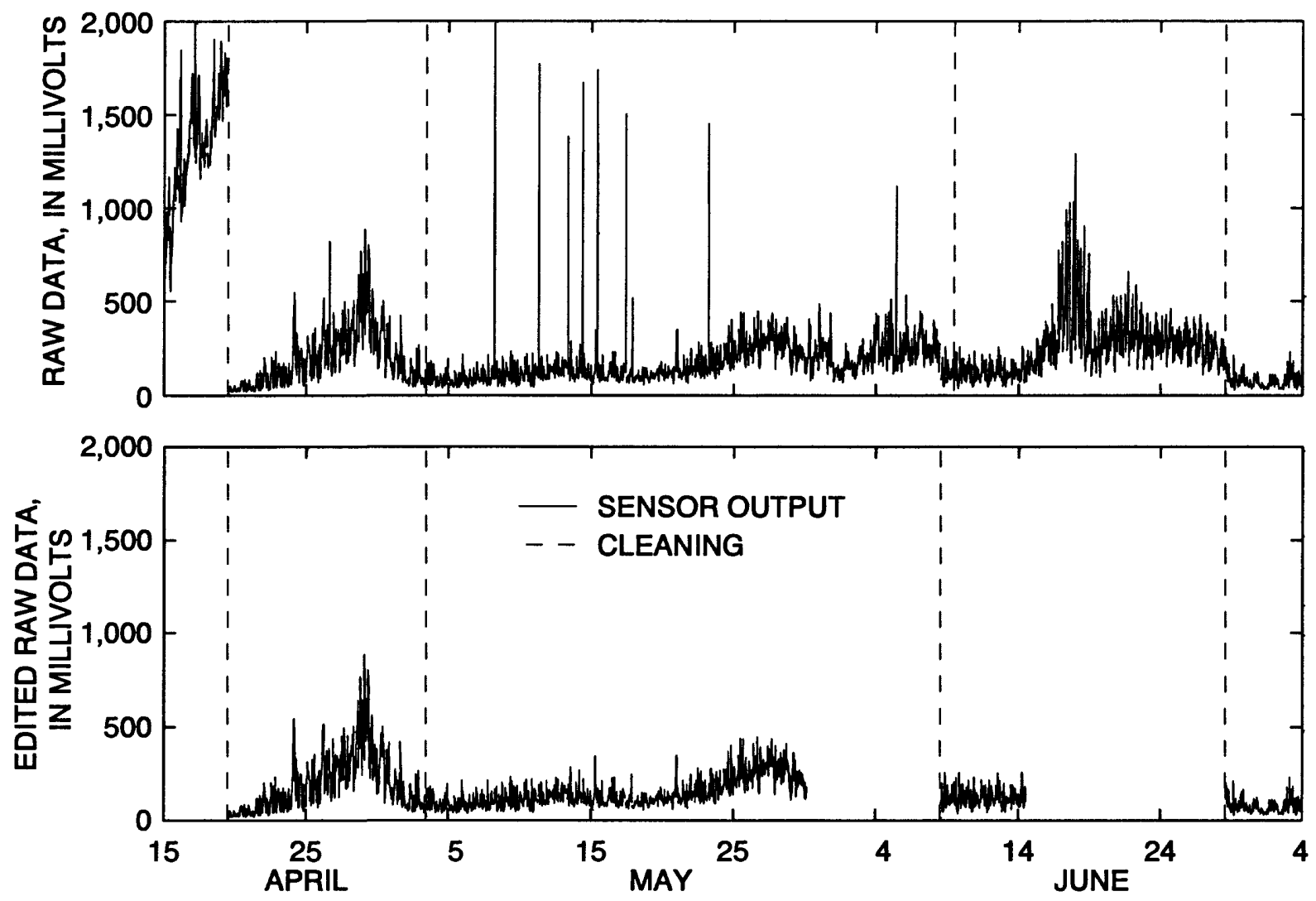

Figure 3. Raw and edited optical backscatterance data, mid-depth sensor, Point San Pablo, Central San Francisco Bay, California, water 1994 (Buchanan and others, 1996).

\section{SENSOR CALIBRATION AND SUSPENDED-SOLIDS CONCENTRATION DATA}

The output from the optical sensors was converted to suspended-solids concentration using the robust, nonparametric, repeated median method (Siegel, 1982). In past annual reports (Buchanan and Schoellhamer, 1995, 1996, 1998, 1999; Buchanan and others, 1996), ordinary least-squares regression had been used to develop calibration curves. However, constant variance of residuals is necessary when using ordinary least squares to obtain the best linear unbiased estimator of suspended-solids concentration (Helsel and Hirsch, 1992, p. 225) and for some of the calibration data sets, the variance of the residuals is not constant, as it increases with voltage. Analyses of different robust methods showed that the robust regression lines were almost always within the reported standard error for ordinary least squares. Robust regression methods are not restricted by the assumption of constant variance of residuals and they minimize the influence of high leverage points. Therefore, given the nature of many of the data sets, robust regression is more appropriate than ordinary least squares for the calibration curves.

The repeated median method calculates the slope in a two part process. First, for each point $(X, Y)$, the median of all possible "point $i$ " to "point $j$ " slopes $\left(\beta_{i}\right)$ is calculated:

$$
\beta_{i}=\operatorname{median} \frac{\left(Y_{j}-Y_{i}\right)}{\left(X_{j}-X_{i}\right)} \quad \text { for all } j \neq i
$$


The calibration slope is calculated as the median of $\beta_{i}$ :

$$
\text { slope }=\hat{\beta}_{1}=\operatorname{median}\left(\beta_{i}\right)
$$

Finally, the calibration intercept is calculated as the median of all possible intercepts using the slope calculated above:

$$
\text { intercept }=\hat{\beta}_{0}=\operatorname{median}\left(Y_{i}-\hat{\beta}_{1} X_{i}\right)
$$

The final linear calibration equation is

$$
Y=\hat{\beta}_{1} X+\hat{\beta}_{0}:
$$

One problem with robust methods is that the familiar ordinary least squares regression statistics are not valid, nor are many alternatives to describe the goodness-of-fit available. In order to best describe the error associated with the regression equations, two different error analyses have been done. The first, a nonparametric prediction interval $\left(\mathrm{PI}_{\mathrm{np}}\right)$, (Helsel \& Hirsch, 1992, p. 76) calculates a constant-width error band that contains 68.26 percent, or one standard deviation, of the calibration data set. The 68.26 percent value was selected because it results in essentially the same error prediction limits as the root-mean-squared (RMS) error of prediction in ordinary least squared regression, which was used in previous data reports (Buchanan and Schoellhamer, 1995, 1996, 1998, 1999; Buchanan and others, 1996), when analyzing a random set of normally distributed data. A prediction interval is more conservative than the corresponding confidence interval, and describes the likelihood that a new observation comes from the same distribution as the initial data set.

It is important to note that the $\mathrm{PI}_{\mathrm{np}}$, unlike the RMS error of prediction, frequently is not symmetrical about the regression line. For example, the $\mathrm{PI}_{\mathrm{np}}$ may be reported as +10 milligram per liter $(\mathrm{mg} / \mathrm{L})$ and $-7 \mathrm{mg} / \mathrm{L}$. This asymmetry about the regression line is a result of the nonnormal distribution of the data set. The $\mathrm{PI}_{\mathrm{np}}$ is calculated by computing and sorting, from least to greatest, the residuals for each point. Then, based on the sorted list of residuals:

$$
\text { nonparametric prediction interval }=P I_{n p}=\hat{Y}_{\left(\frac{\alpha}{2}\right)(n+1)} \text { to } \hat{Y}_{\left(1-\frac{\alpha}{2}\right)(n+1)}
$$

where $\hat{Y}$ is the residual value,

$n$ is the number of data points, and $\alpha$ is the confidence level of 0.6826 .

To provide an alternate tool to analyze the calibration data, a second percent error method was developed. The percent error of each point was calculated as:

$$
\text { percent error }=\mathrm{PE}=\frac{Y_{\text {actual }}-Y_{\text {predicted }}}{Y_{\text {predicted }}}
$$

Then the percent error band was calculated in the same manner as the $\mathrm{PI}_{\mathrm{np}}$, described above, except that in place of the residual values, $\hat{Y}$, the percent error, $P E$, was used. 
Table 1. Statistical summary of suspended-solids concentration data, Suisun Bay and Central and South San Francisco Bays, California, water year 1998

[All measurements are in milligrams per liter. Lower quartile is 25 th percentile; upper quartile is 75 th percentile]

\begin{tabular}{|c|c|c|c|c|c|c|c|}
\hline Site & Latitude & Longitude & Depth & Mean & Median & $\begin{array}{l}\text { Lower } \\
\text { quartile }\end{array}$ & $\begin{array}{l}\text { Upper } \\
\text { quartile }\end{array}$ \\
\hline Mallard Island & $38^{\circ} 02^{\prime} 34^{\prime \prime}$ & $121^{\circ} 55^{\prime} 09^{\prime \prime}$ & $\begin{array}{l}\text { Near-surface } \\
\text { Near-bottom }\end{array}$ & $\begin{array}{l}46 \\
47\end{array}$ & $\begin{array}{l}43 \\
41\end{array}$ & $\begin{array}{l}37 \\
29\end{array}$ & $\begin{array}{l}52 \\
59\end{array}$ \\
\hline Benicia Bridge & $38^{\circ} 02^{\prime} 42^{\prime \prime}$ & $122^{\circ} 07^{\prime} 32^{\prime \prime}$ & $\begin{array}{l}\text { Near-surface } \\
\text { Near-bottom }\end{array}$ & $\begin{array}{r}73 \\
141\end{array}$ & $\begin{array}{r}68 \\
104\end{array}$ & $\begin{array}{l}53 \\
61\end{array}$ & $\begin{array}{r}86 \\
170\end{array}$ \\
\hline Carquinez Bridge & $38^{\circ} 03^{\prime} 41^{\prime \prime}$ & $122^{\circ} 13^{\prime} 23^{\prime \prime}$ & $\begin{array}{l}\text { Mid-depth } \\
\text { Near-bottom }\end{array}$ & $\begin{array}{r}71 \\
290\end{array}$ & $\begin{array}{r}55 \\
216\end{array}$ & $\begin{array}{r}41 \\
136\end{array}$ & $\begin{array}{r}94 \\
386\end{array}$ \\
\hline Point San Pablo & $37^{\circ} 57^{\prime} 53^{\prime \prime}$ & $122^{\circ} 25^{\prime} 42^{\prime \prime}$ & $\begin{array}{l}\text { Mid-depth } \\
\text { Near-bottom }\end{array}$ & $\begin{array}{r}83 \\
110\end{array}$ & $\begin{array}{l}67 \\
81\end{array}$ & $\begin{array}{l}40 \\
50\end{array}$ & $\begin{array}{l}104 \\
138\end{array}$ \\
\hline Pier 24 & $37^{\circ} 47^{\prime} 27^{\prime \prime}$ & $122^{\circ} 23^{\prime} 05^{\prime \prime}$ & $\begin{array}{l}\text { Mid-depth } \\
\text { Near-bottom }\end{array}$ & $\begin{array}{l}28 \\
38\end{array}$ & $\begin{array}{l}26 \\
30\end{array}$ & $\begin{array}{l}14 \\
24\end{array}$ & $\begin{array}{l}36 \\
41\end{array}$ \\
\hline Channel Marker 17 & $37^{\circ} 28^{\prime} 44^{\prime \prime}$ & $122^{\circ} 04^{\prime} 38^{\prime \prime}$ & $\begin{array}{l}\text { Mid-depth } \\
\text { Near-bottom }\end{array}$ & $\begin{array}{l}200 \\
210\end{array}$ & $\begin{array}{l}122 \\
140\end{array}$ & $\begin{array}{l}65 \\
76\end{array}$ & $\begin{array}{l}257 \\
274\end{array}$ \\
\hline Dumbarton Bridge & $37^{\circ} 30^{\prime} 15^{\prime \prime}$ & $122^{\circ} 07^{\prime} 10^{\prime \prime}$ & $\begin{array}{l}\text { Mid-depth } \\
\text { Near-bottom }\end{array}$ & $\begin{array}{r}92 \\
257\end{array}$ & $\begin{array}{r}67 \\
213\end{array}$ & $\begin{array}{r}39 \\
131\end{array}$ & $\begin{array}{l}113 \\
323\end{array}$ \\
\hline San Mateo Bridge & $37^{\circ} 35^{\prime} 04^{\prime \prime}$ & $122^{\circ} 14^{\prime} 59^{\prime \prime}$ & $\begin{array}{l}\text { Mid-depth } \\
\text { Near-bottom }\end{array}$ & $\begin{array}{l}44 \\
36\end{array}$ & $\begin{array}{l}35 \\
30\end{array}$ & $\begin{array}{l}22 \\
18\end{array}$ & $\begin{array}{l}53 \\
46\end{array}$ \\
\hline
\end{tabular}

Table 2. Percentage of valid data collected by optical backscatterance sensors, Suisun Bay, and Central and South San Francisco Bays, California, water year 1998

\begin{tabular}{llc}
\hline \multicolumn{1}{c}{ Site } & \multicolumn{1}{c}{ Depth } & Percent valid data \\
\hline Mallard Island & Near-surface & 65 \\
& Near-bottom & 89 \\
Benicia Bridge & Near-surface & 73 \\
& Near-bottom & 77 \\
Carquinez Bridge & Mid-depth & 38 \\
& Near-bottom & 67 \\
Point San Pablo & Mid-depth & 73 \\
& Near-bottom & 84 \\
Pier 24 & Mid-depth & 45 \\
& Near-bottom & 62 \\
Channel Marker 17 & Mid-depth & 41 \\
& Near-bottom & 32 \\
Dumbarton Bridge & Mid-depth & 60 \\
& Near-bottom & 70 \\
San Mateo Bridge & Mid-depth & 55 \\
& Near-bottom & 48 \\
\hline
\end{tabular}


A statistical summary of the calculated suspended-solids concentrations and the percentage of valid data collected by optical backscatterance sensors at each site is presented in tables 1 and 2 , respectively. This section of the report also includes the robust regression (calibration) plots for optical sensor output [in millivolts $(\mathrm{mV})$ ] versus suspended-solids concentration (in $\mathrm{mg} / \mathrm{L}$ ). The repeated median regression plots include the number of samples (data points), the calculated linear correlation equation, the nonparametric prediction interval (shown on the plots as a grey band), and the percent error (shown on the plots as a dash-dot line). Finally, the time-series plots of suspended-solids concentration data are shown for each site.

\section{Suisun Bay}

\section{Mallard Island}

The calibration of the near-surface self-cleaning probe (fig. 4A) was calibrated from samples collected from December 9, 1994, through September 30, 1998; flood samples collected from January through March 1995, January through February 1997 and February through March 1998 were excluded. The calibration of the near-bottom self-cleaning probe (fig. 5A) was calibrated from samples collected from April 20, 1995, through September 30, 1998; flood samples collected from January through February 1997 and February through March 1998 were excluded. Flood waters caused a small shift in the calibration of the near-surface and near-bottom sensors from February 1 through April 4, 1998. The calibration of the near-surface self-cleaning sensor used during flood conditions was developed with 18 samples collected during the floods of water year 1995, 4 samples collected in water year 1997, and 2 samples collected in water year 1998 (fig. 4B). The calibration of the near-bottom self-cleaning sensor used during flood conditions was developed with nine samples collected during the floods of water year 1995, four samples collected during water year 1997, and three samples collected in water year 1998 (fig. 5B). Between February 1-3 and March 31-April 4, the slope and intercept of the flood and normal calibration curves for both sensors were interpolated to transition smoothly between the two calibrations. Suspended-solids concentration data collected during water year 1998 are presented in figure 6. 


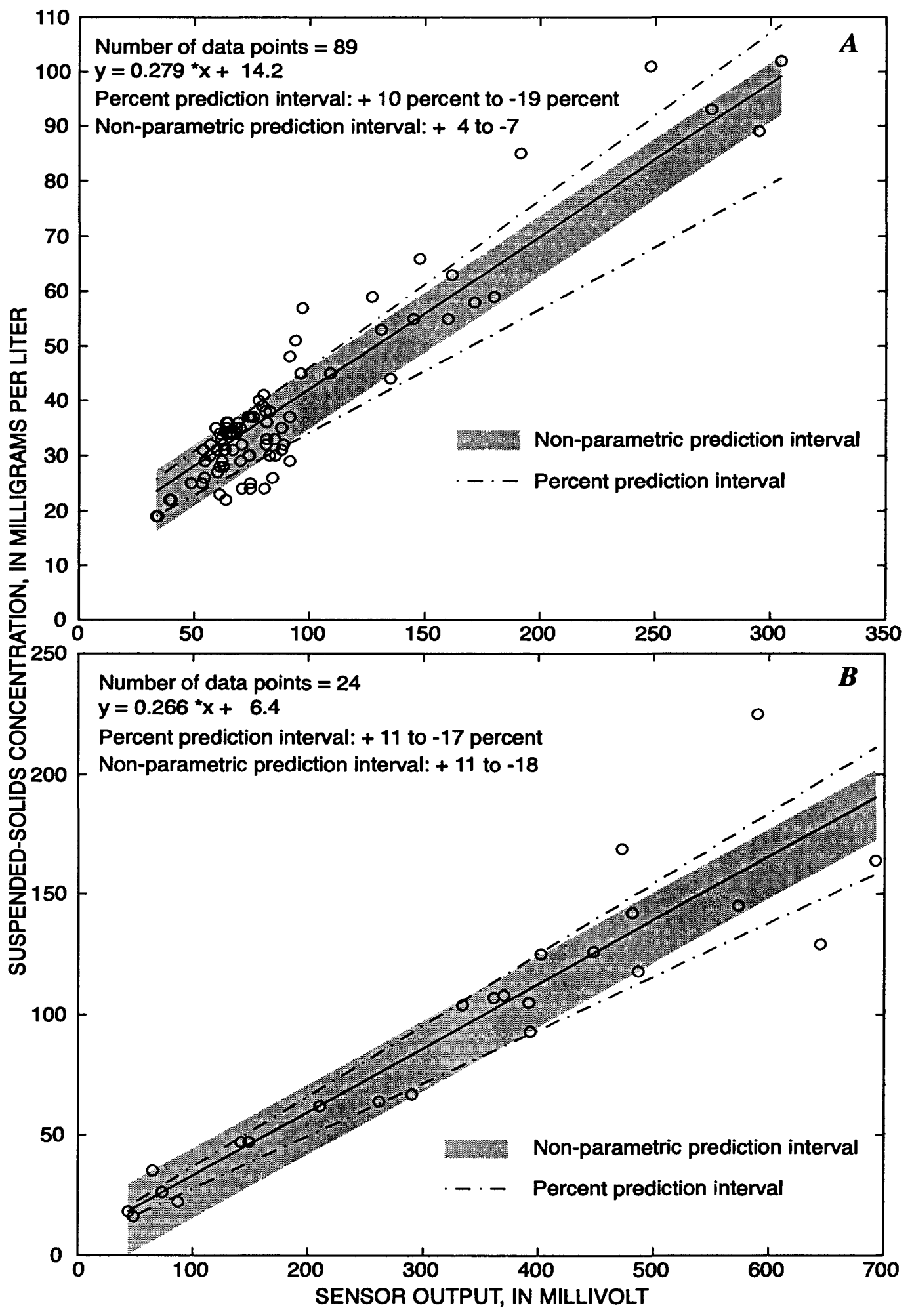

Figure 4. Calibration of near-surface optical backscatterance senson during normal conditions, 0ctober 1January 31 and April 5-September 30 (A) and during flood conditions, February 1-April 4 (B) at Mallard Island, Suisun Bay, California, water year 1998. 


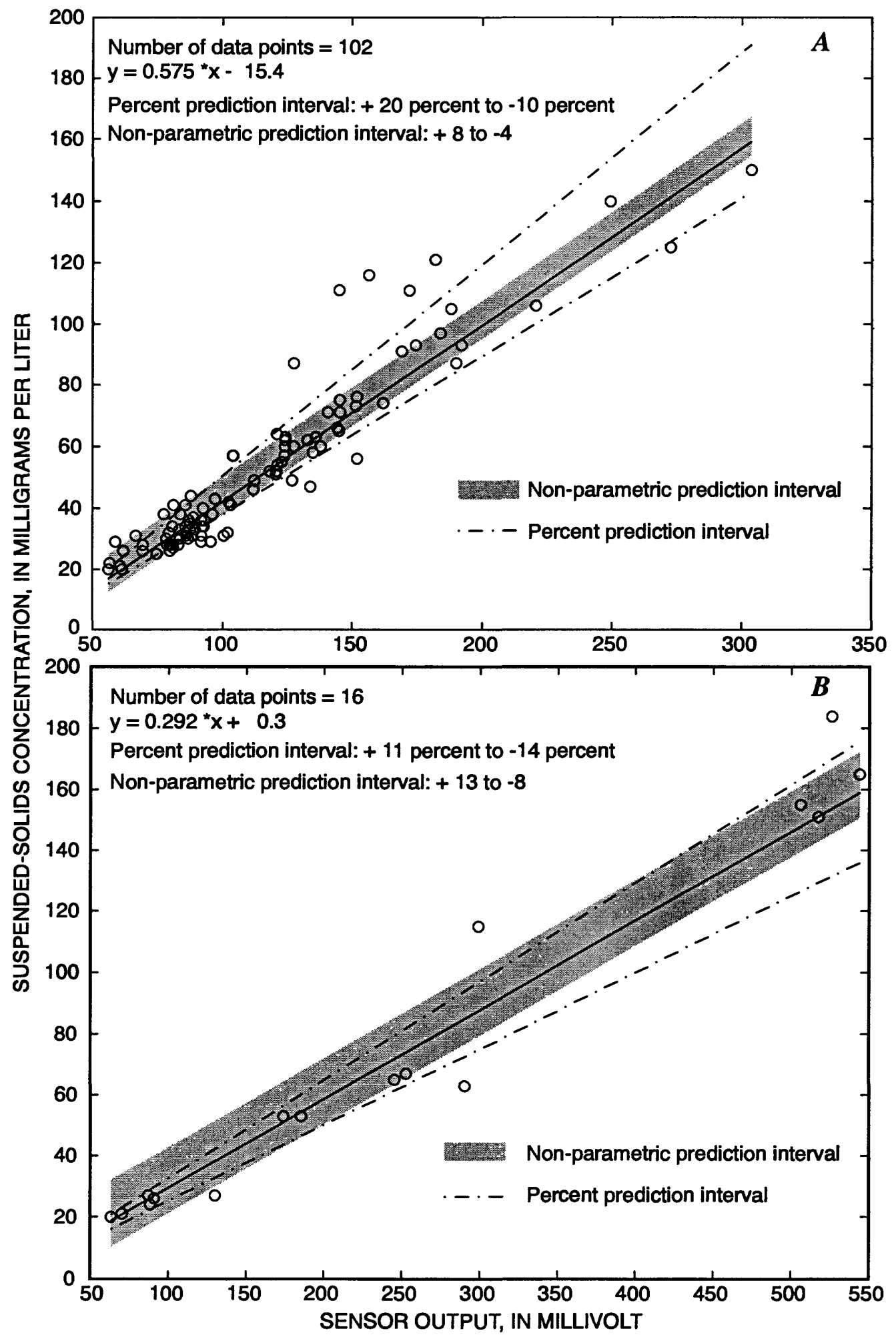

Figure 5. Calibration of near-bolttom optical backscatterance senson during normal conditions, 0ctober 1January 31 and April 5-September 30 (A) and during flood conditions, February 1-April 4 (B) at Mallard Island, Suisun Bay, California, water year 1998. 


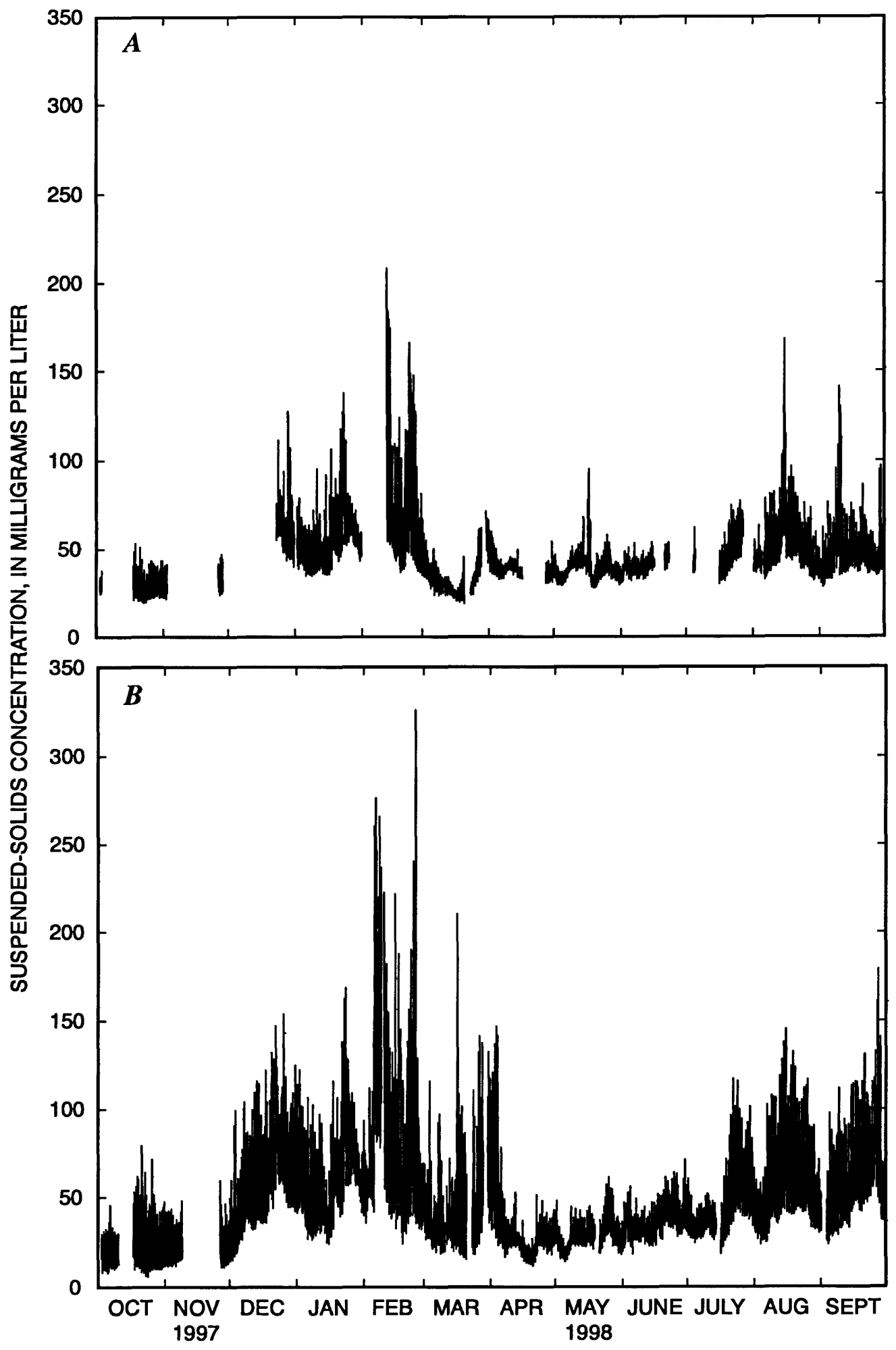

Figure 6. Time series of near-surface (A) and near-bottom (B) suspended-solids concentrations calculated from sensor readings at Mallard Island, Suisun Bay, California, water year 1998. 


\section{Benicia Bridge}

Sensors without the self-cleaning function were deployed on May 14, 1996. The calibration of the near-surface sensor was developed using 34 water samples collected from May 14, 1996, through water year 1998 (fig. 7A). The calibration of the near-bottom sensor was developed using 24 water samples collected from March 5, 1997, through water year 1998 (fig. 7B). A -243-mV shift to the record, calculated from visual inspection of the time series record, was applied from November 18 through December 18, 1997, to correct for an unexplained shift in sensor output. The suspension cable was found broken on August 7, 1998, and was not replaced because of the seismic retrofitting operation to be started in September 1998 on the Benicia Bridge. Suspended-solids concentration data collected during water year 1998 are presented in figure 8 . 


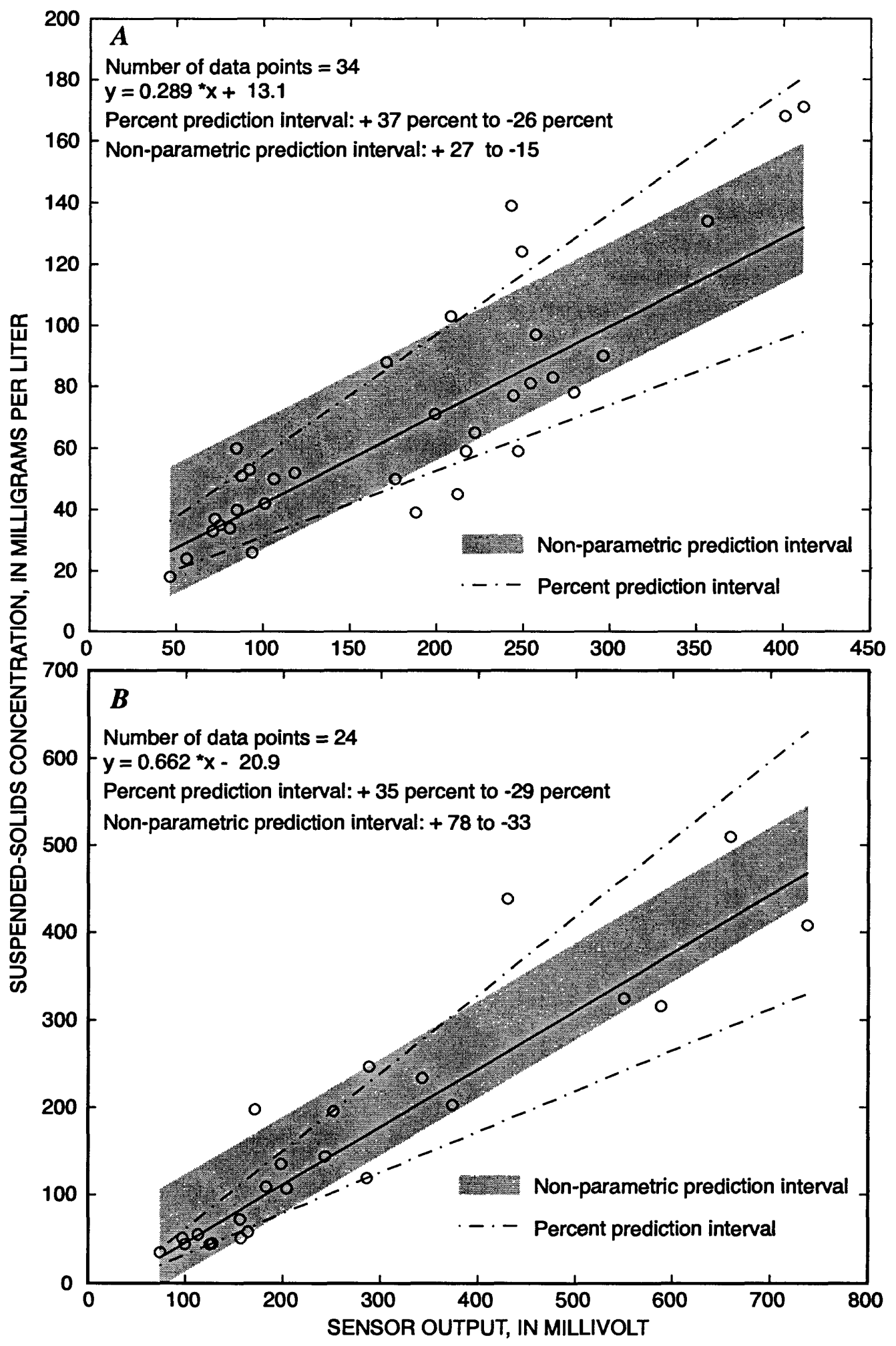

Figure 7. Calibration of near-surface (A) and near-bottom (B) optical backscatterance sensors at Benicia Bridge, Suisun Bay, California, water 1998. 


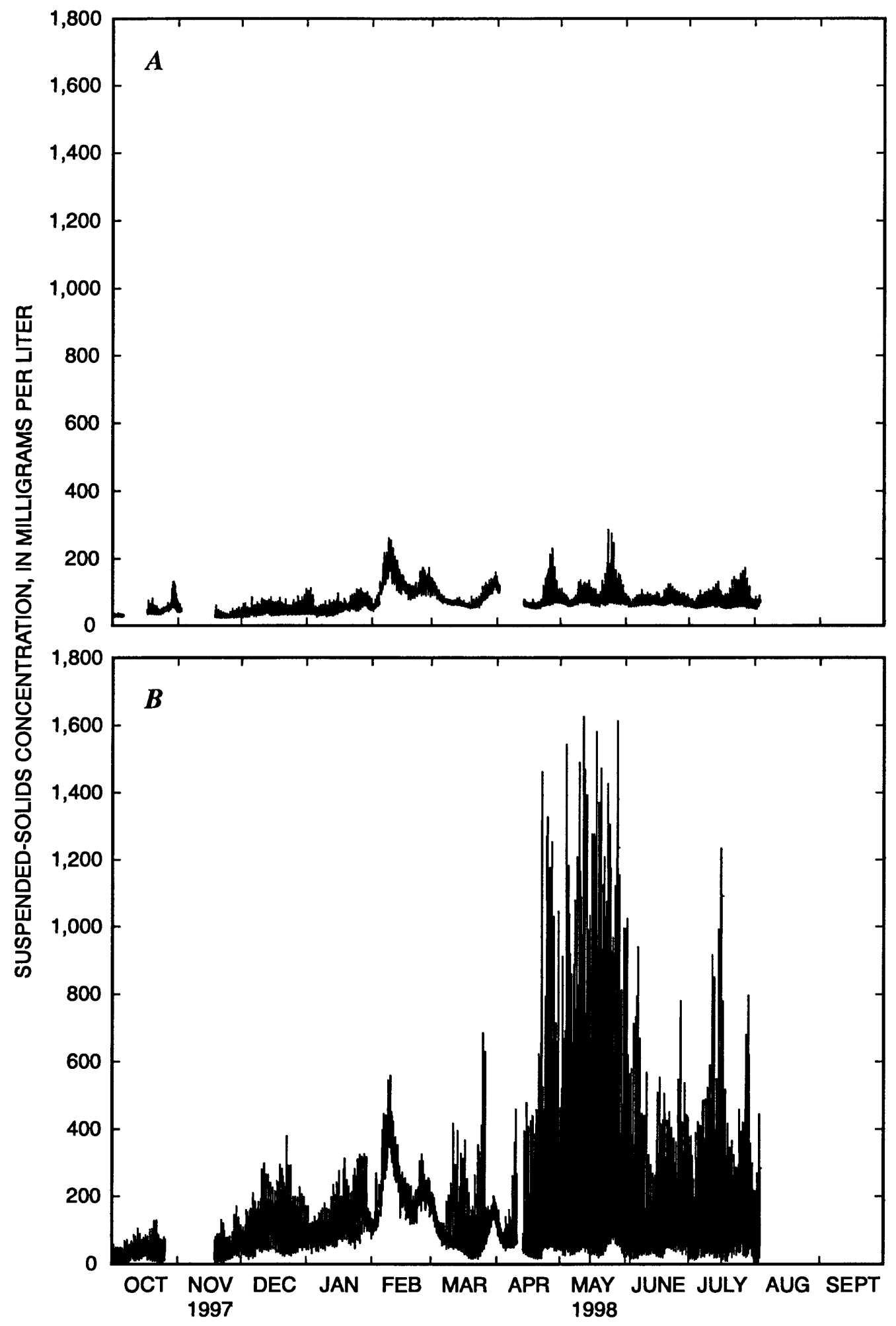

Figure 8. Time series of near-surface (A) and near-bottom (B) suspended-solids concentrations calculated from sensor readings at Benicia Bridge, Suisun Bay, California, water year 1998. 


\section{Central San Francisco Bay}

\section{Carquinez Bridge}

A single calibration was used for the mid-depth and near-bottom sensors and was developed from 13 water samples collected from June 23 through December 11, 1998 (fig. 9). Using a single calibration for both sensors was possible because the sensors were factory calibrated using the same NTU standard; they were verified by on-site field checks during the period of deployment using NTU standards of varying concentrations. The mid-depth sensor did not become operational until June 23, 1998, because of problems with the optical sensor on the sonde. The near-bottom optical sensor was operational from April 21 through May 15, 1998, when it, too, became inoperable because of problems with the optical sensor; it was replaced on June 3,1998. The optical sensors on the sondes can measure a maximum of 1,000 NTU, which was sometimes exceeded at the near-bottom depth during April-May 1998. Suspended-solids concentration data collected during water year 1998 are presented in figure 10.

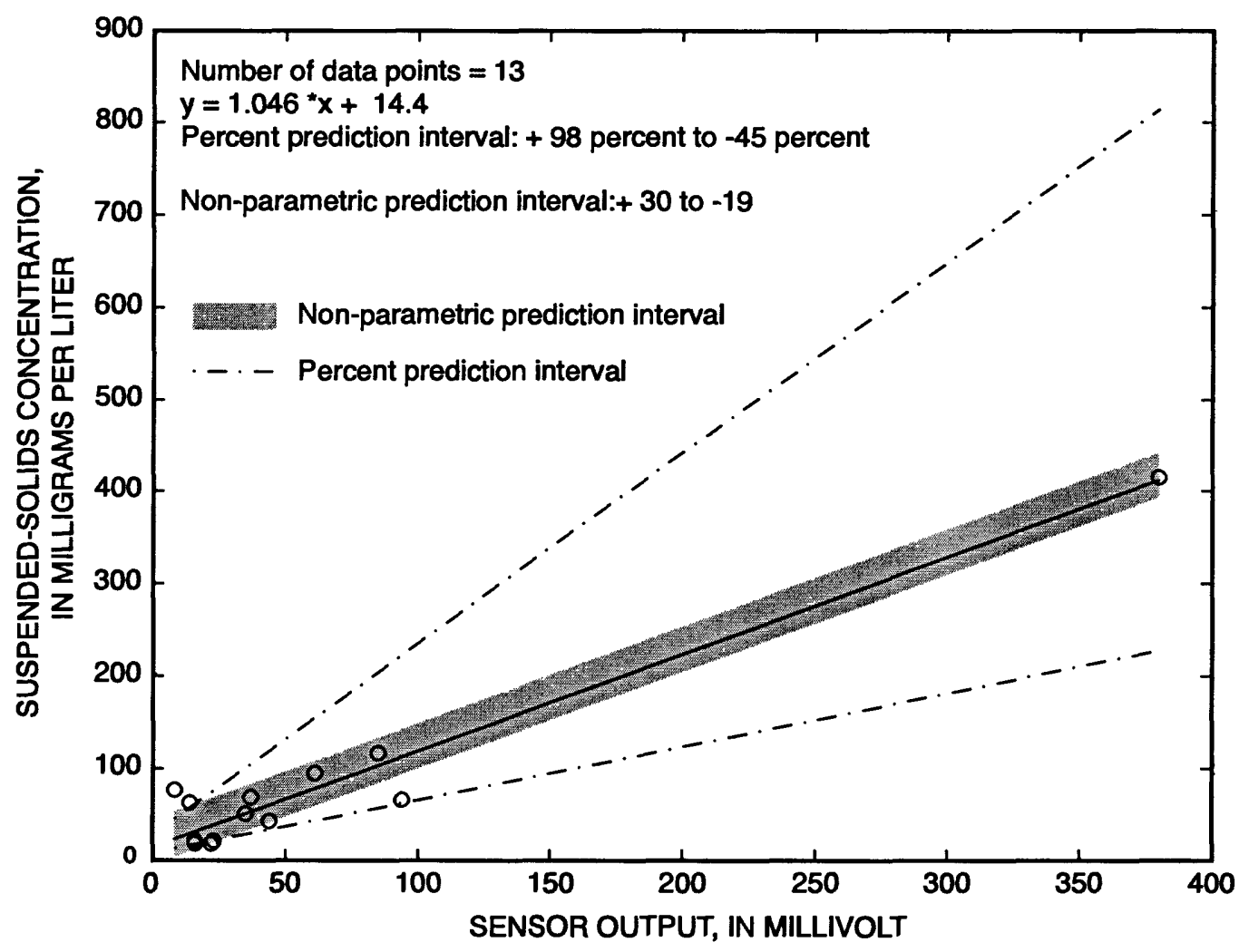

Figure 9. Calibration of mid-depth and near-bottom optical backscatterance sensors at Carquinez Bridge, Centrat San Francisco Bay, California, water year 1998. 


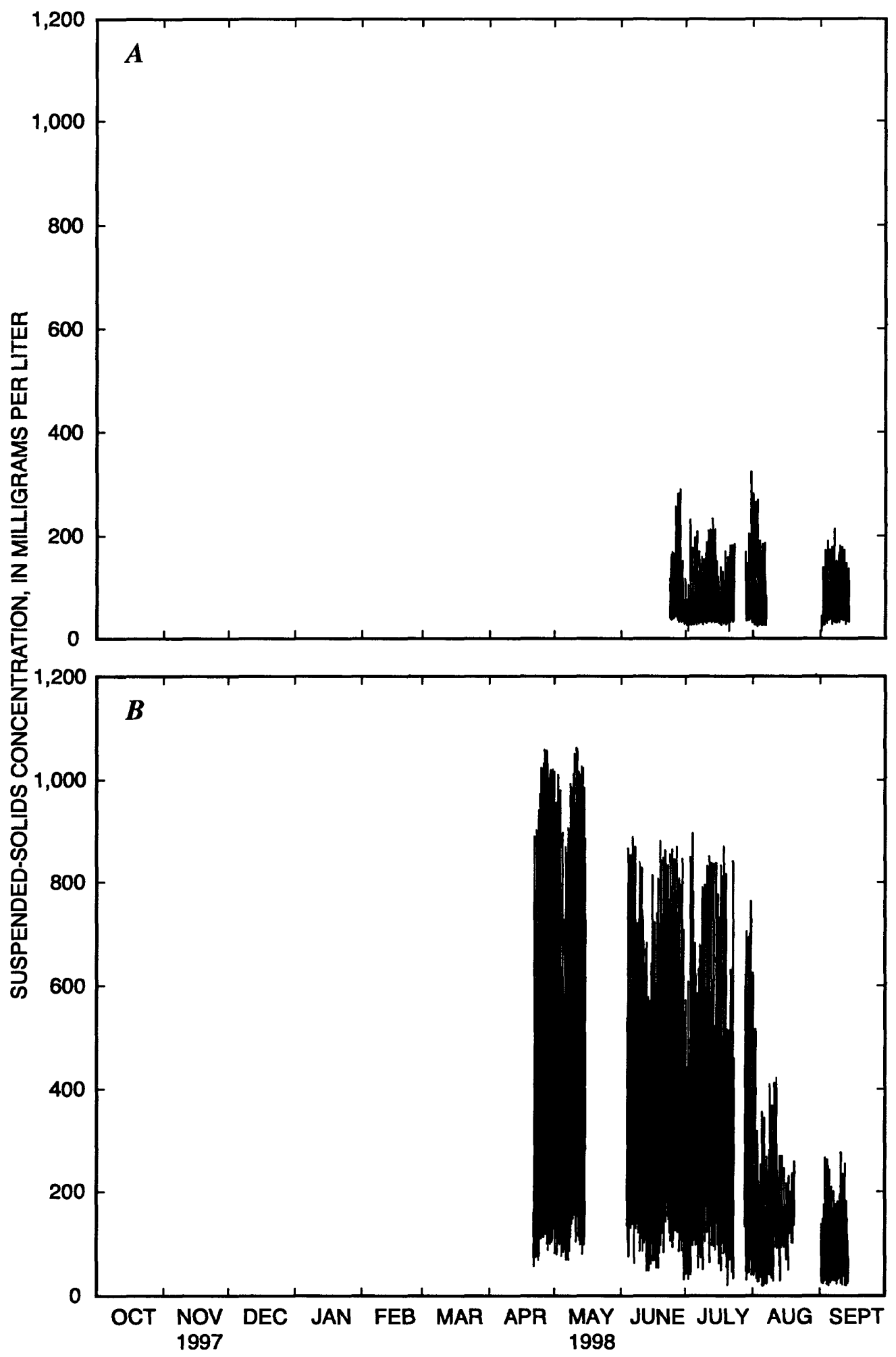

Figure 10. Time series of mid-depth (A) and near-bottom (B) suspended-solids concentrations calculated from sensor readings at Carquinez Bridge, Central San Francisco Bay, California, water year 1998. 


\section{Point San Pablo}

The calibration of the mid-depth sensor was developed using 65 water samples collected from August 15, 1995, through water year 1998 (fig. 11A). The calibration of the near-bottom sensor was developed using 82 water samples collected from August 15, 1995, through water year 1998 (fig. 11B). During October 1997, the near-bottom sensor was operating erratically, possibly due to a problem with the data logger, and many spikes were edited from the data set. Suspended-solids concentration data collected during water year 1998 are presented in figure 12. 


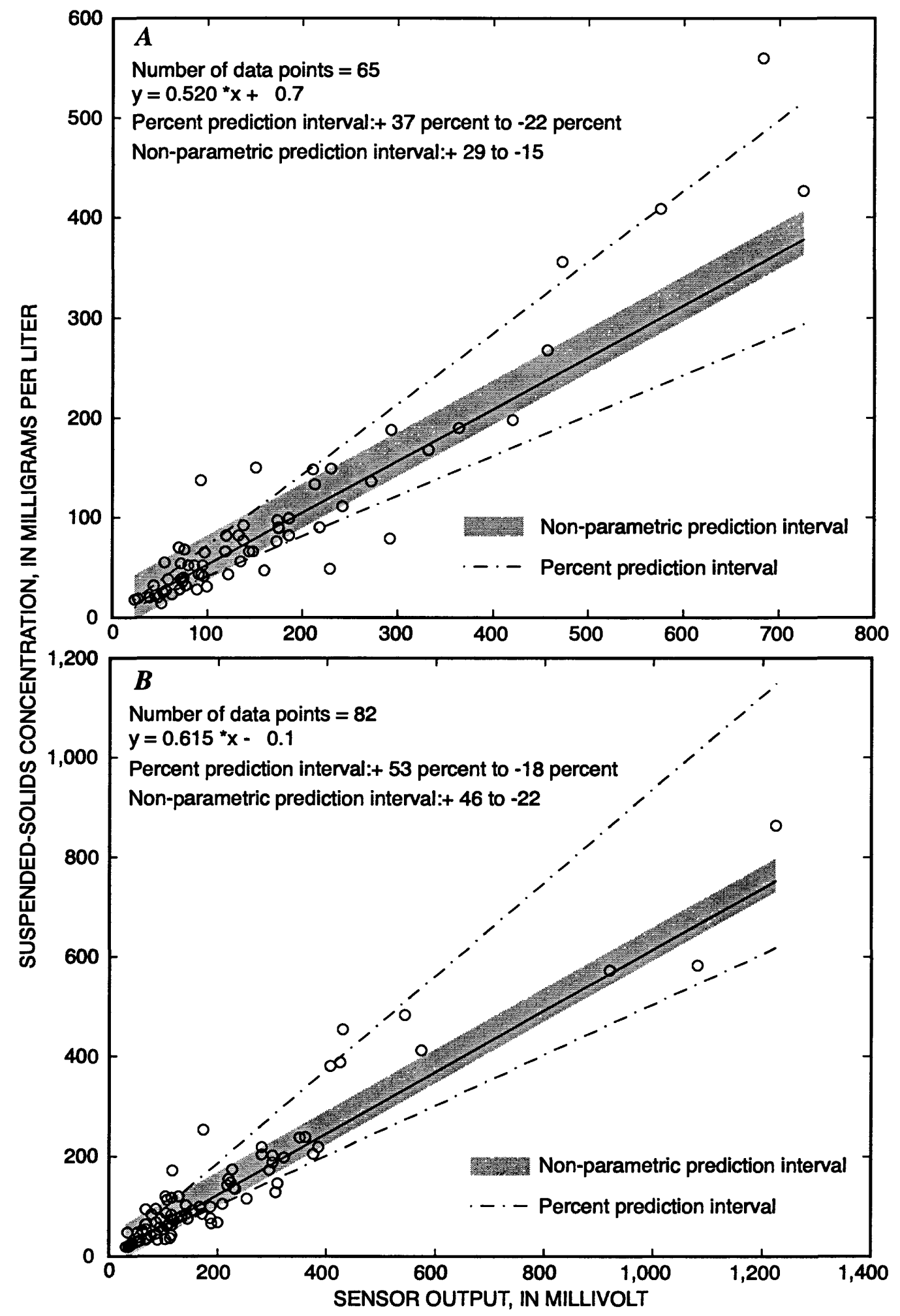

Figure 11. Calibration of mid-depth (A) and near-bottom (B) optical backscatterance sensors at Point San Pablo, Central San Francisco Bay, California, water year 1998. 


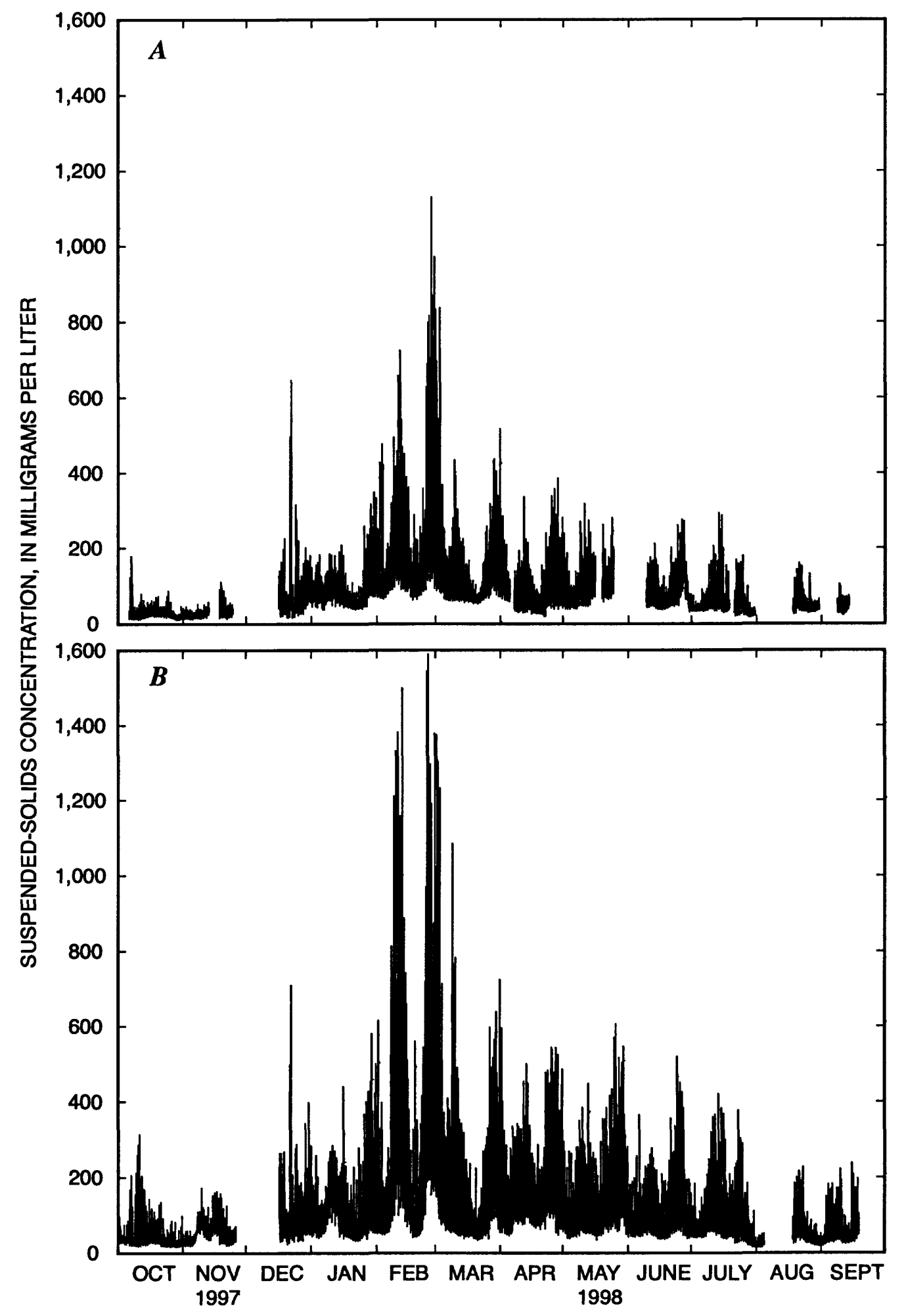

Figure 12. Time series of mid-depth (A) and near-bottom (B) suspended-solids concentrations calculated from sensor readings at Point San Pablo, Central San Francisco Bay, California, water year 1998. 


\section{Pier 24}

Calibration of the mid-depth sensor prior to May 20, 1998, was developed from 26 water samples collected from April 1996 through April 1998 (fig. 13A). The mid-depth sensor failed sometime in April 1998 and was replaced on May 20, 1998. The calibration of the mid-depth sensor in place from May 20 through September 30, 1998, was developed from ten water samples collected from May 20 through December 1998 (fig. 13B). A 50-mV shift to the middepth record (calculated from water-sample data not shown on figure 13B) was applied from November 18 to December 17, 1997, to correct for a shift in sensor output. Calibration of the near-bottom sensor was developed from 65 water samples collected from June 22, 1995, through water year 1998 (fig. 14). Suspended-solids concentration data collected during water year 1998 are presented in figure 15. 


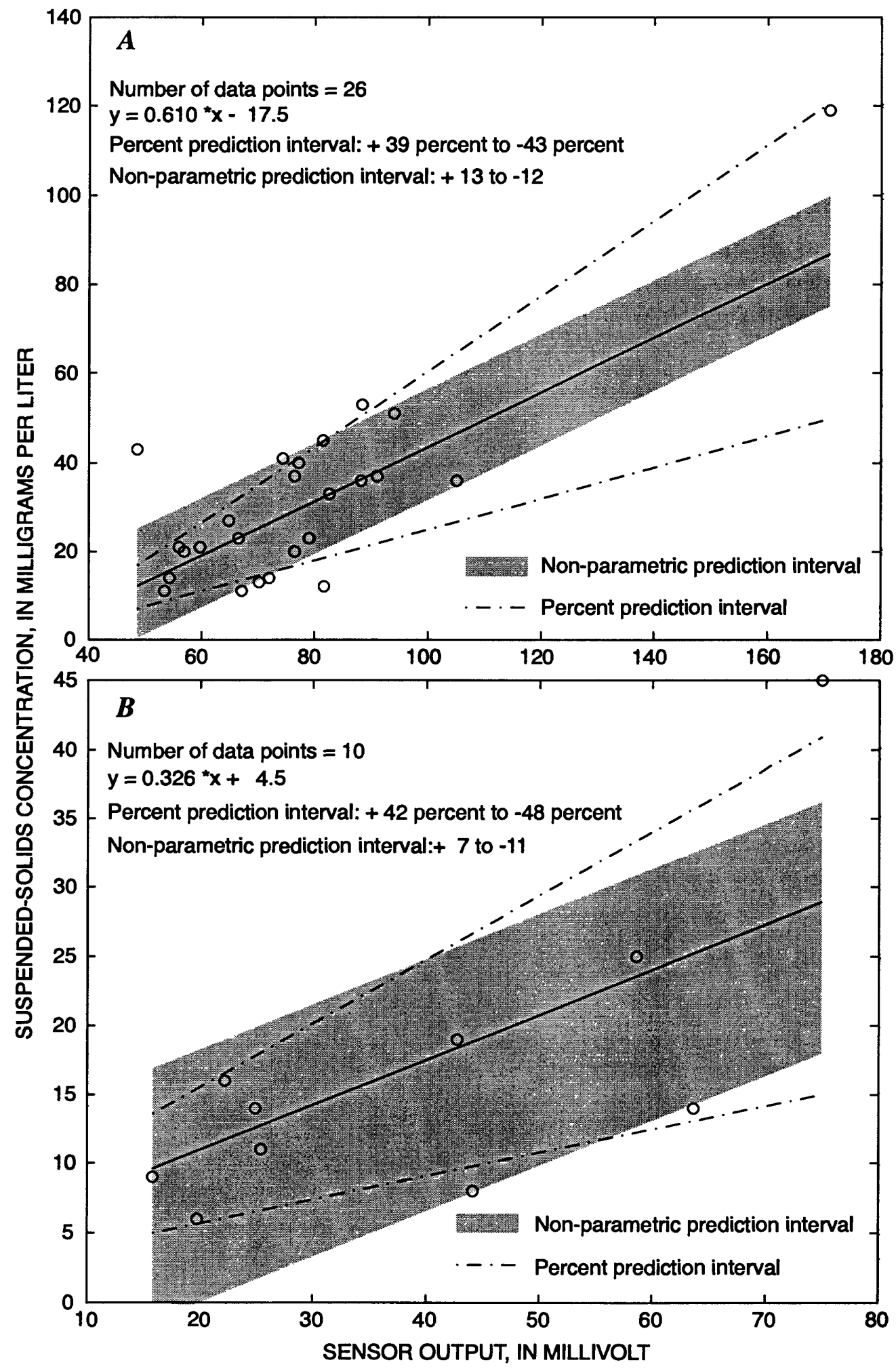

Figure 13. Calibration of mid-depth optical backscatterance sensors at Pier 24, Central San Francisco Bay, California, October 1-May 19 (A) and May 20-September 30 (B), water year 1998. 


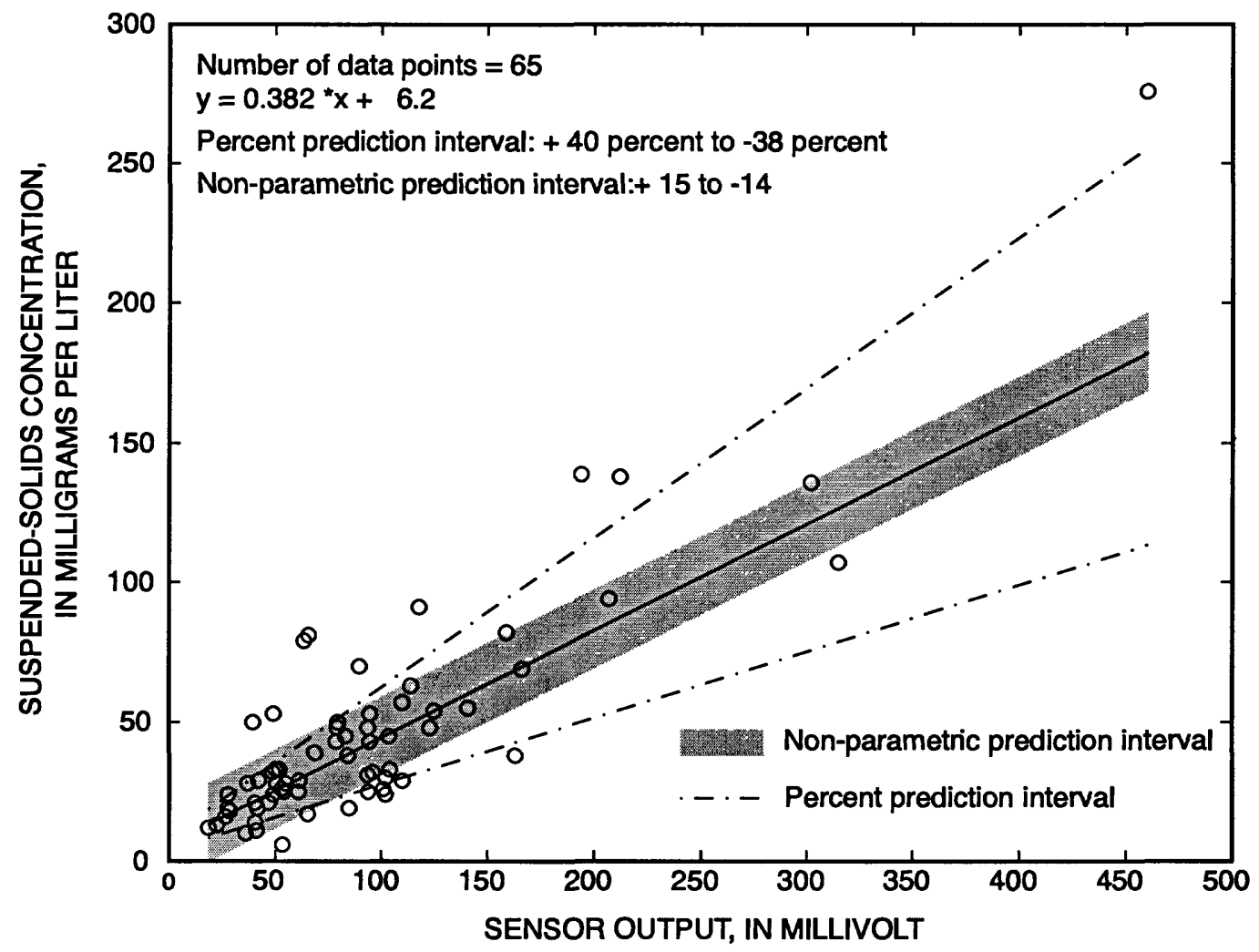

Figure 14. Calibration of near-bottom optical backscatterance sensor at Pier 24, Central San Francisco Bay, California, water year 1998. 


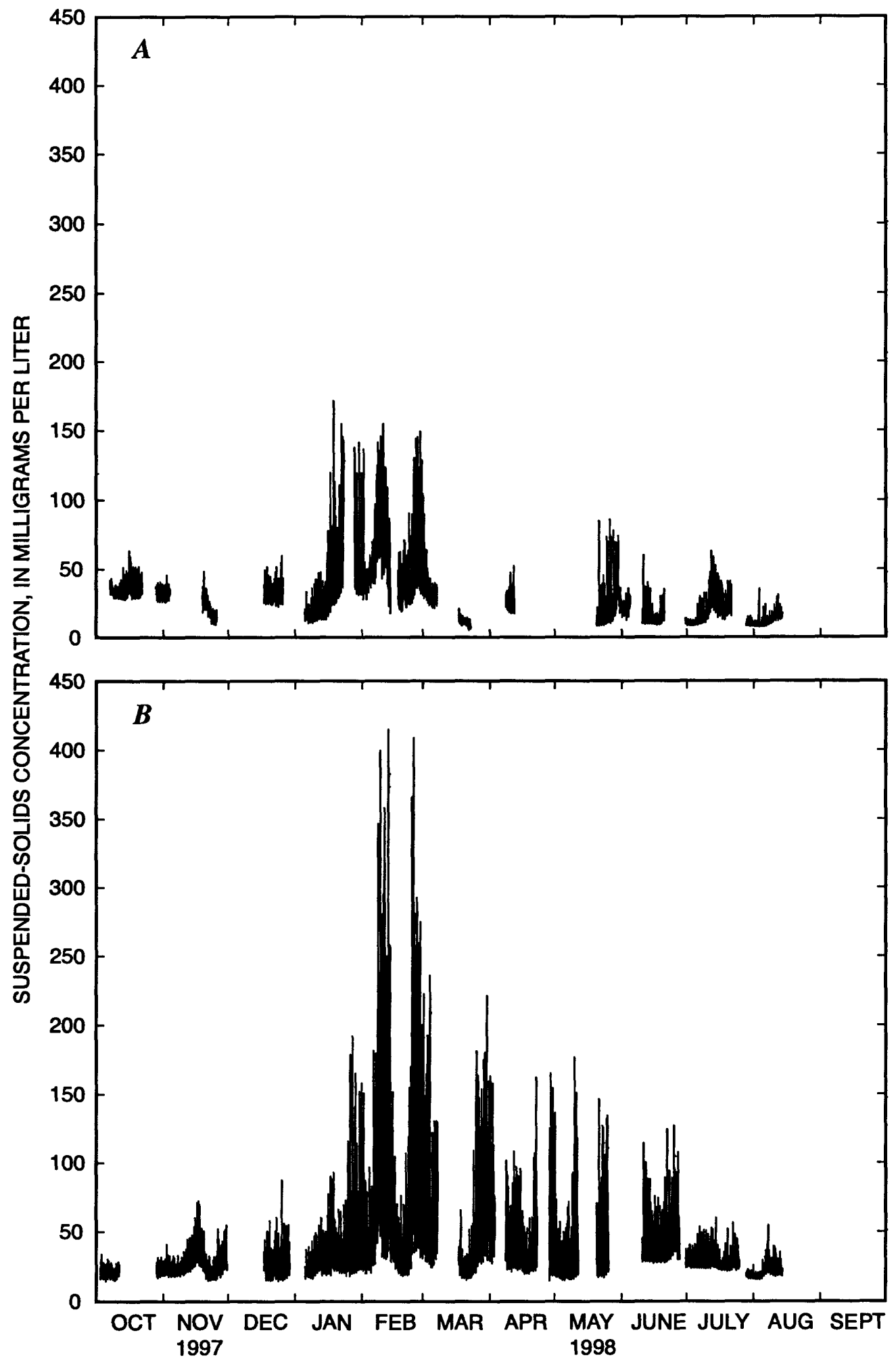

Figure 15. Time series of mid-depth (A) and near-bottom (B) suspended-solids concentrations calculated from sensor readings at Pier 24, Central San Francisco Bay, California, water year 1998. 


\section{South San Francisco Bay}

\section{Channel Marker 17}

The calibration of the mid-depth sensor was developed from 29 water samples collected from February 26 through September 30, 1998 (fig. 16). A -132-mV shift to the record (calculated from water-sample data not shown on figure 16) was applied from January 16 through March 18, 1998. The mid-depth sensor cable was damaged, which resulted in a loss of data from October 1 through October 30, 1997; the sensor cable was replaced. The calibration of the near-bottom sensor was developed from 62 water samples collected from October 7, 1994, through July 30, 1998 (fig. 17A). A -71-mV shift to the record (calculated from water-sample data not shown on figure 17A) was applied from January 16 through March 18, 1998. The nearbottom sensor failed sometime in July and was replaced on July 30,1998 . The calibration of the near-bottom replacement sensor was developed from 14 water samples collected from July 30 , 1998, through February 11, 1999 (fig. 17B). Water-sample data from water year 1999 were used because of the few water samples collected in water year 1998. Suspended-solids concentration data collected during water year 1998 are presented in figure 18.

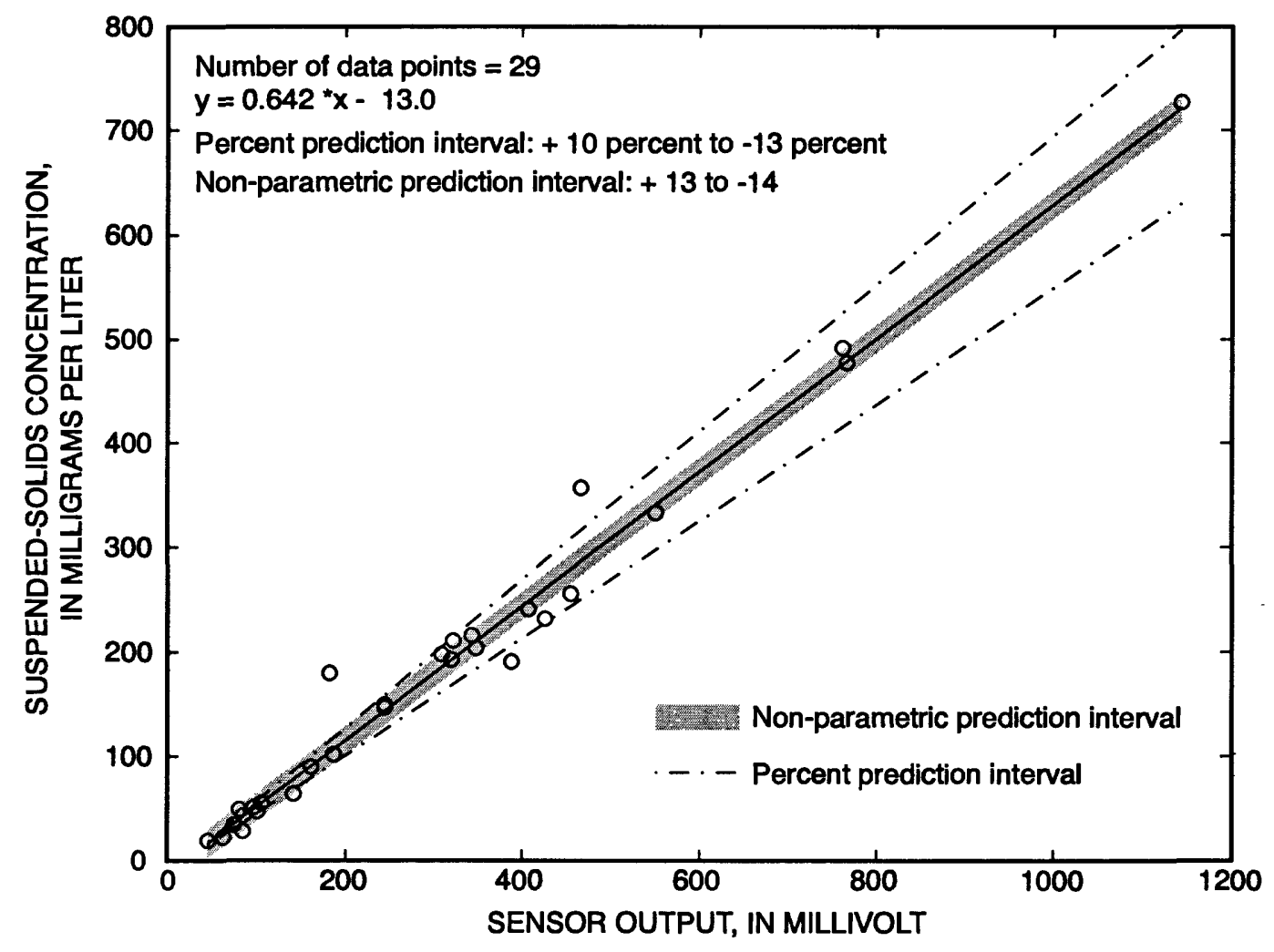

Figure 16. Calibration of mid-depth optical backscatterance sensor at Channel Marker 17, South San Francisco Bay, California, water year 1998. 


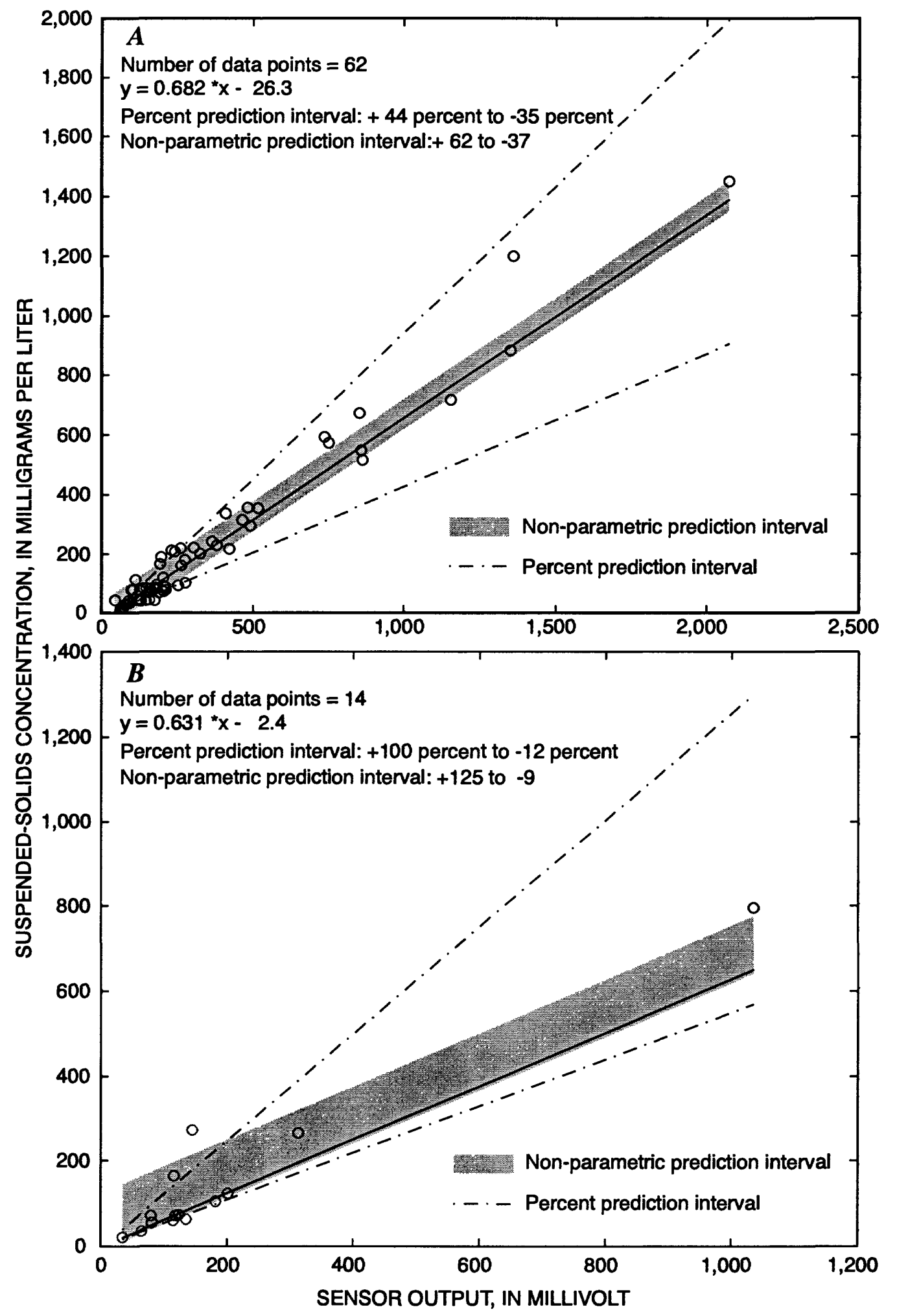

Figure 17. Calibration of near-bottom optical backscatterance sensors at Channel Marker 17, South San Francisco Bay, California, October 1-July 29 (A) and July 30-September 30 (B), water year 1998. 


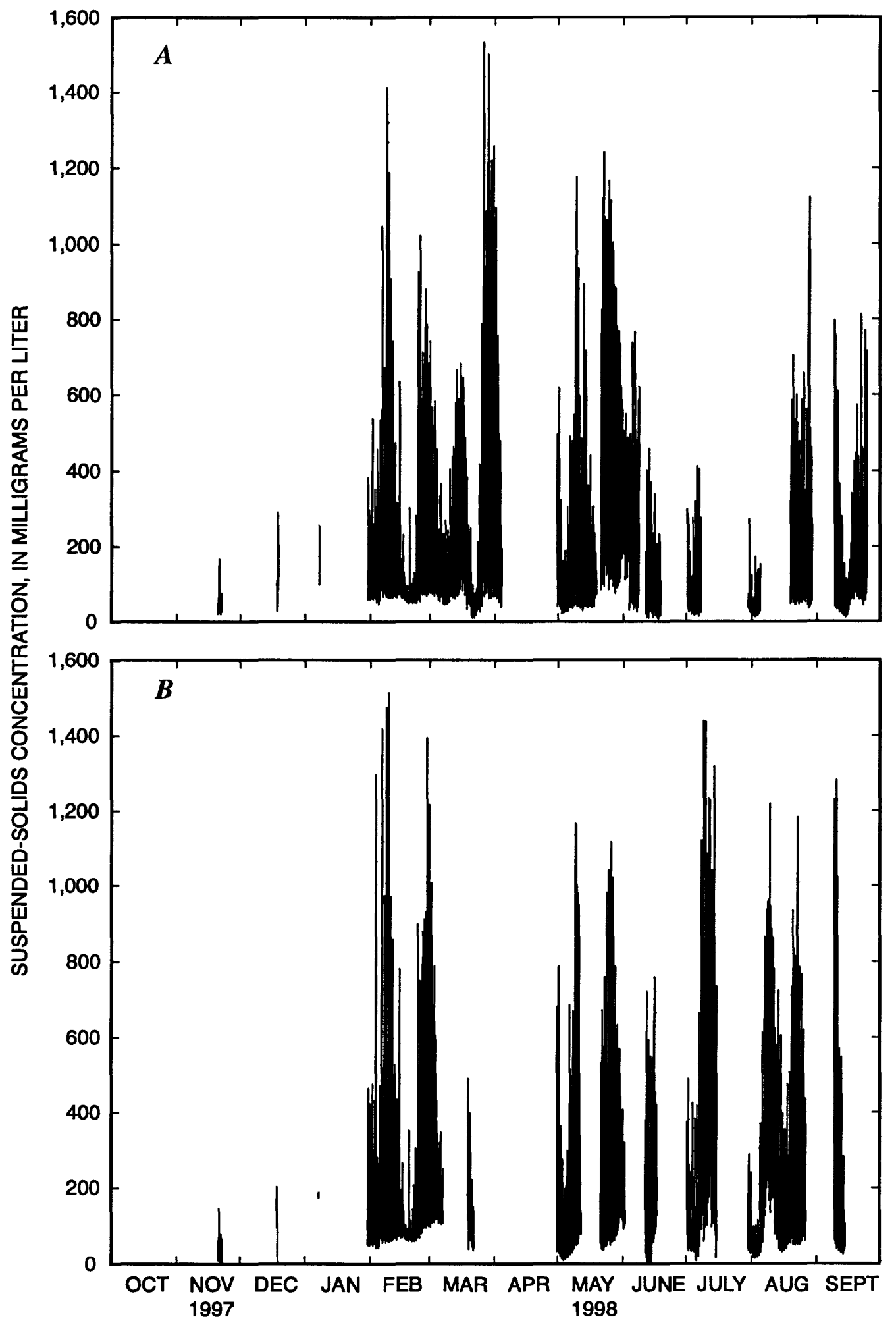

Figure 18. Time series of mid-depth (A) and near-bottom (B) suspended-solids concentrations calculated from sensor readings at Channel Marker 17, South San Francisco Bay, California, water year 1998. 


\section{Dumbarton Bridge}

The calibration of the mid-depth sensor was developed from 62 water samples collected from June 18, 1996, through September 30, 1998 (fig. 19). A -155-mV shift to the record (calculated from water-sample data not shown on figure 19) was applied from January 30 through March 18, 1998. The calibration of the near-bottom sensor was developed from 38 water samples collected from August 14, 1997, through July 1, 1998 (fig. 20A). The near-bottom sensor was damaged during a site visit on July 1,1998 , and was replaced. The calibration of the near-bottom replacement sensor was developed from six water samples collected from July 1 through September 30, 1998 (fig. 20B). Fouling on the suspension cable interfered with the operation of the near-bottom sensor from July 30 through August 20, 1998, when the suspension cable was cleaned. Suspended-solids concentration data collected during water year 1998 are presented in figure 21 .

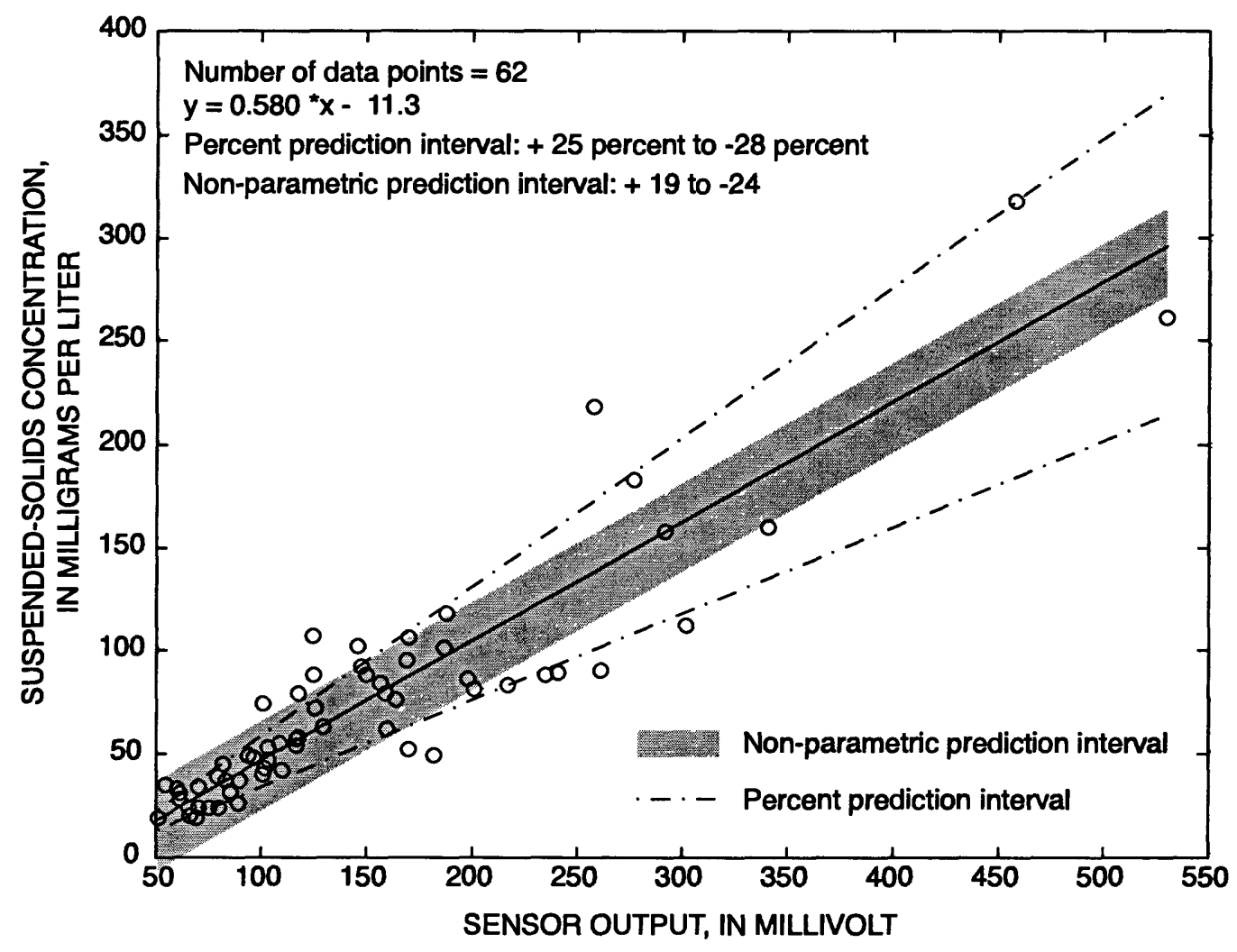

Figure 19. Calibration of mid-depth optical backscatterance sensor at Dumbarton Bridge, South San Francisco Bay, California, water year 1998. 


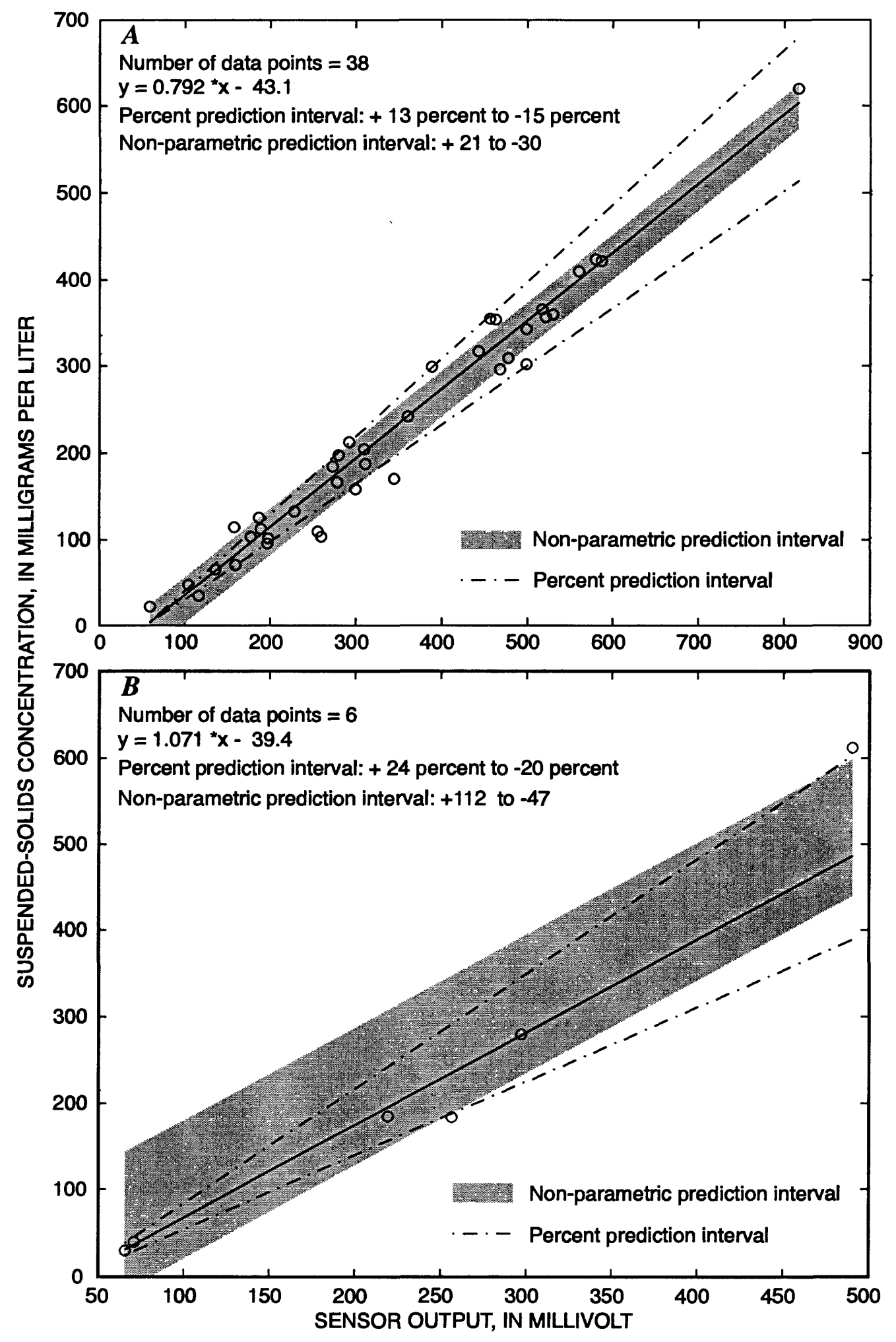

Figure 20. Calibration of near-bottom optical backscatterance sensors at Dumbarton Bridge, South San Francisco Bay, California, October 1-July 1 (A) and July 1-September 30 (B), water year 1998. 


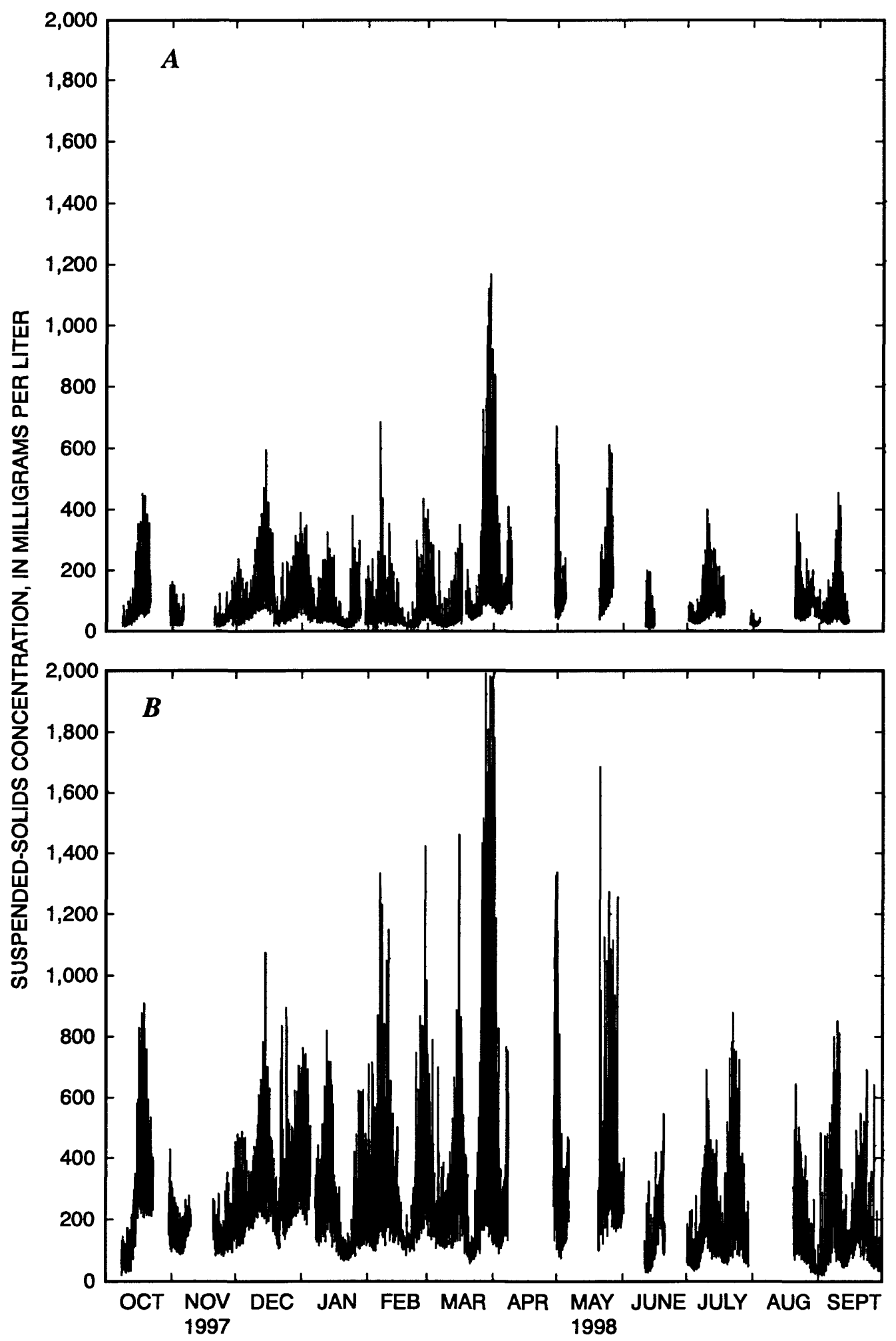

Figure 21. Time series of mid-depth (A) and near-bottom (B) suspended-solids concentrations calculated from sensor readings at Dumbarton Bridge, South San Francisco Bay, California, water year 1998. 


\section{San Mateo Bridge}

The calibration of the mid-depth sensor was developed from 28 water samples collected from March 13, 1997, through September 30, 1998 (fig. 22). A -131-mV shift to the mid-depth record (calculated from water-sample data not shown on figure 22) was applied from June 30 through July 29,1998 . The calibration of the near-bottom sensor was developed from 31 water samples collected from January 11, 1996, through April 9, 1998 (fig. 23A). The near-bottom sensor was replaced on April 9, 1998, when a check against a formazin standard showed a major drift in sensor output. The calibration of the near-bottom replacement sensor was developed from 14 water samples collected from April 9, 1998, through January 12, 1999 (fig. 23B). Watersample data from water year 1999 were used because of the few water samples collected in water year 1998. Shifts to the near-bottom depth record, calculated from water-sample data not shown on figures $23 \mathrm{~A}$ and 23B, were applied to the following periods: $-69 \mathrm{mV}$, December 18 , 1997, through January 7, 1998; -25 mV, January 29 through February 20, 1998; -65 mV, February 20 through March 19, 1998; -122 mV, May 22 through June 10, 1998, and $-75 \mathrm{mV}$, June 10 through June 30,1998. The calibration developed for the near-bottom replacement sensor is considered poor. Suspended-solids concentration data collected during water year 1998 are presented in figure 24.

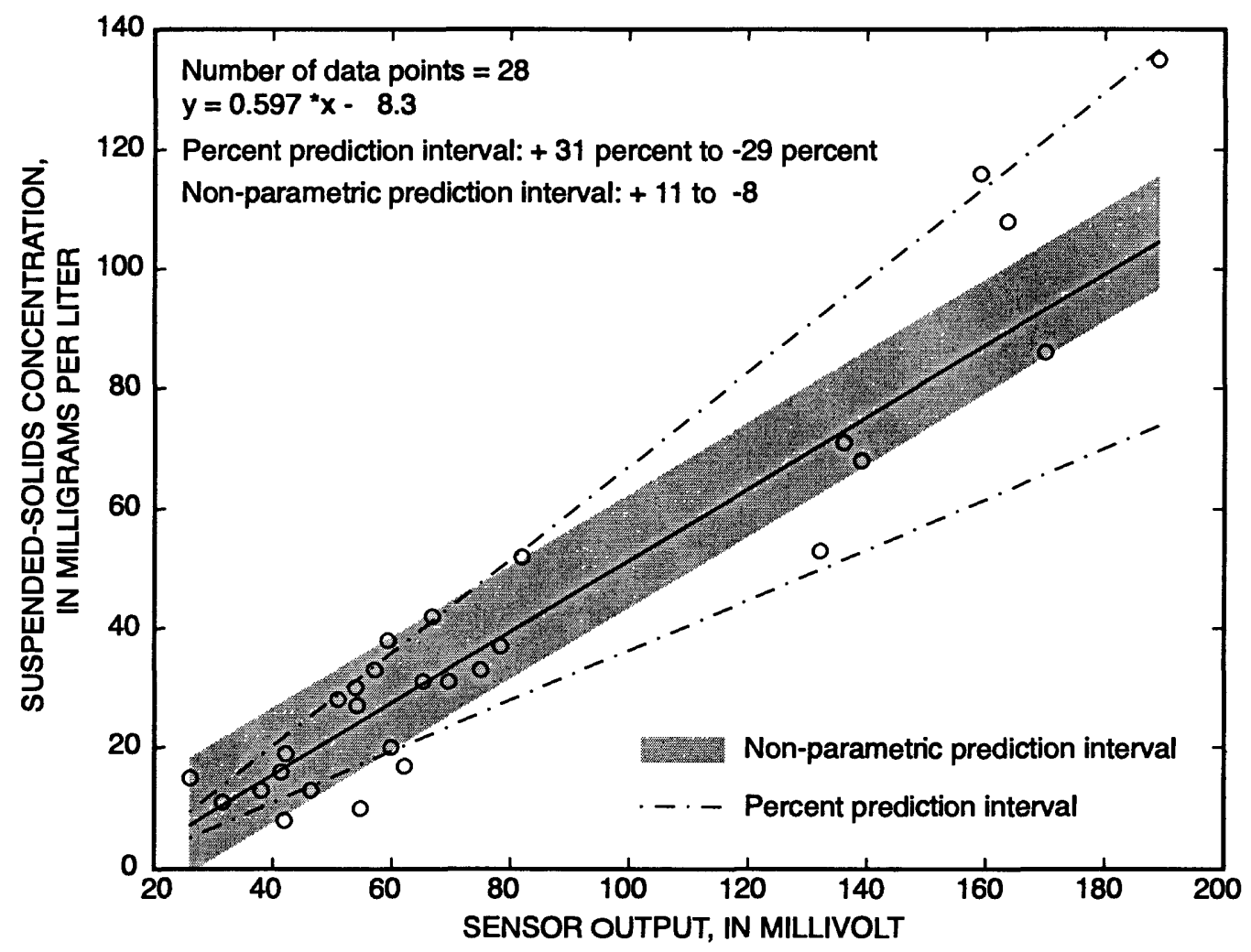

Figure 22. Calibration of mid-depth optical backscatterance sensor at San Mateo Bridge, South San Francisco Bay, California, water year 1998. 


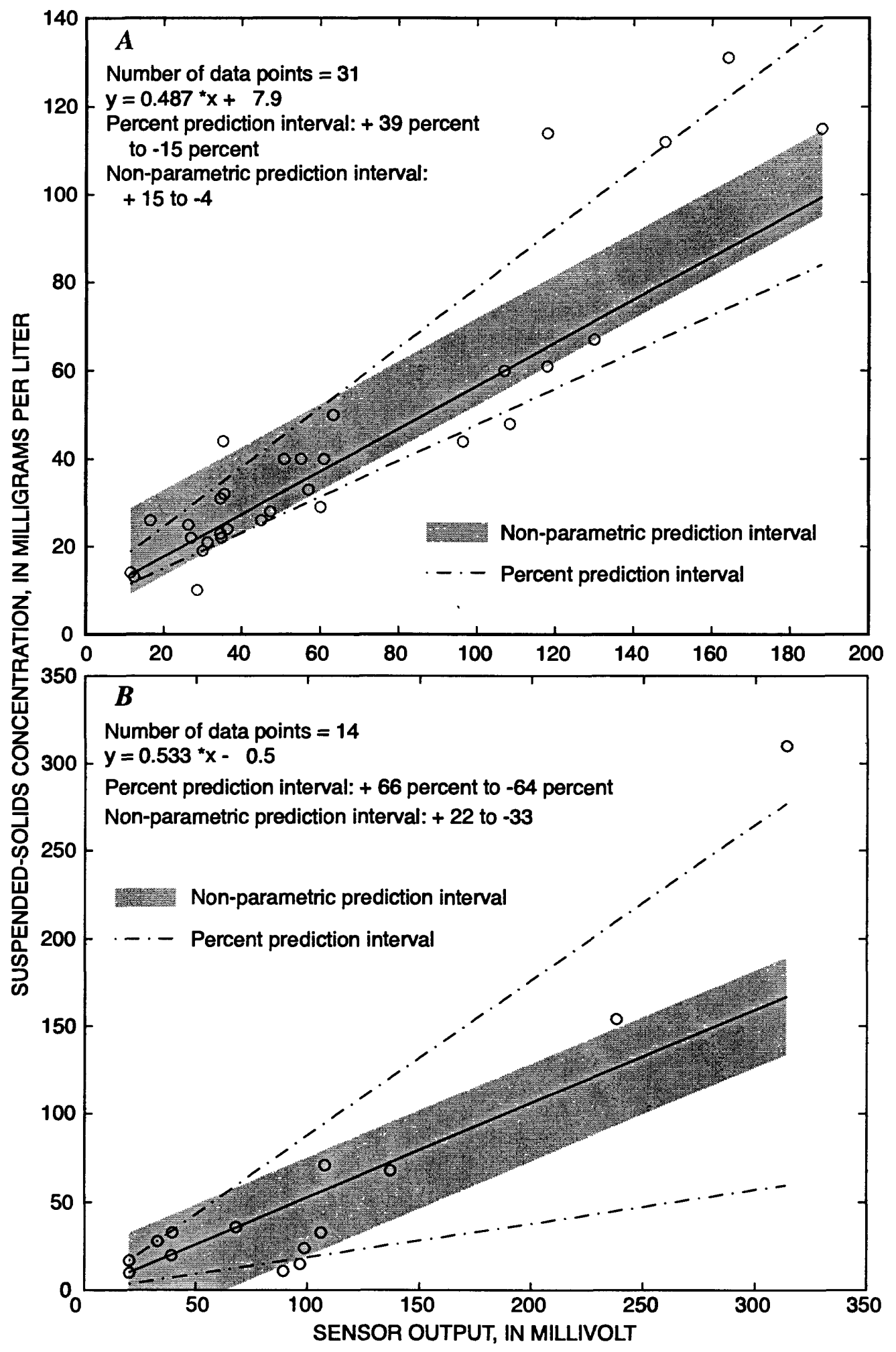

Figure 23. Calibration of near-bottom optical backscatterance sensors at San Mateo Bridge, South San Francisco Bay, California, October 1-April 8 (A) and April 9-September 30 (B), water year 1998. 


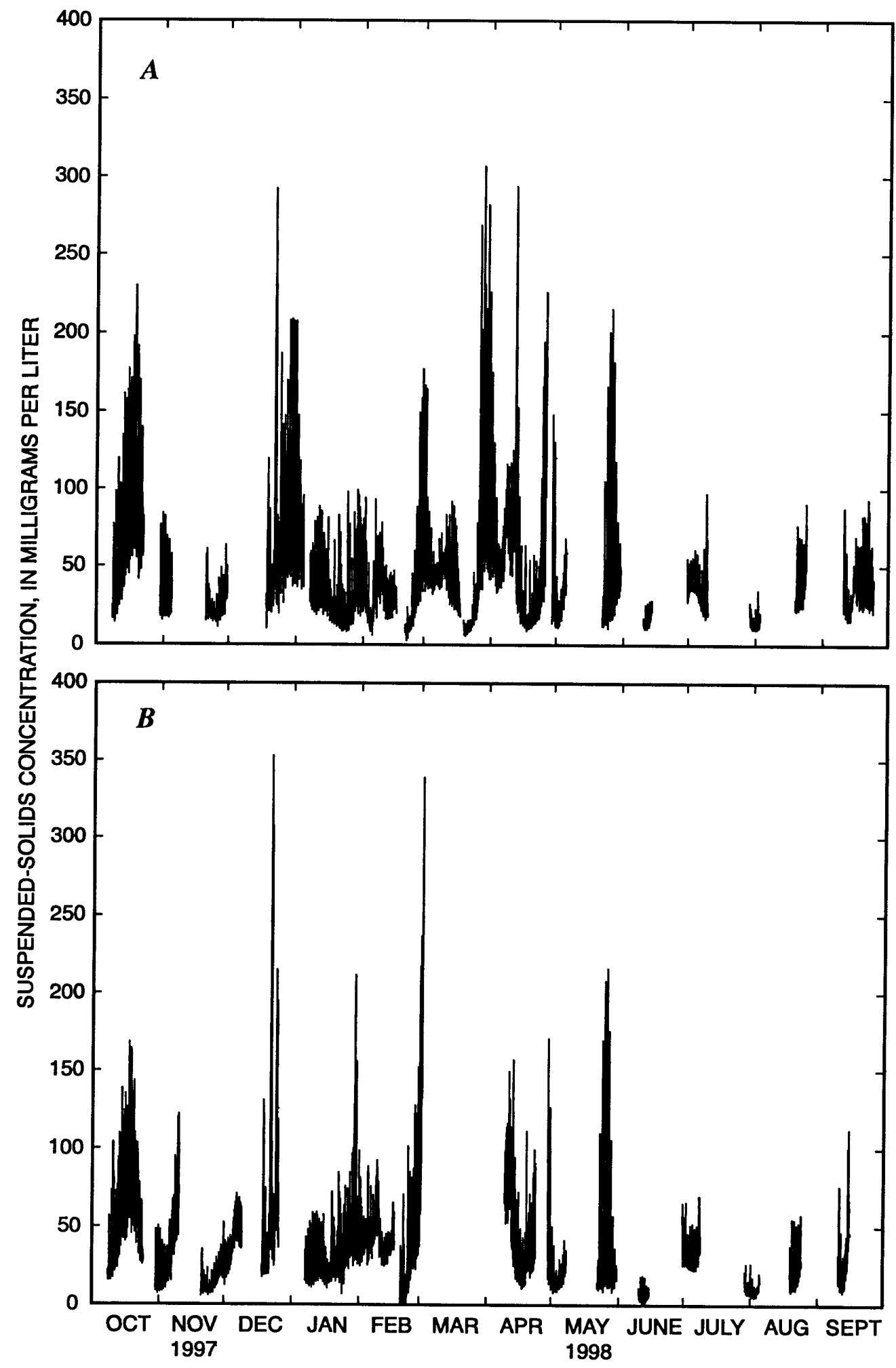

Figure 24. Time series of mid-depth (A) and near-bottom (B) suspended-solids concentrations calculated from sensor readings at San Mateo Bridge, South San Francisco Bay, California, water year 1998. 


\section{SUMMARY}

Suspended-solids concentration data were collected by the U.S. Geological Survey (USGS) at two sites in Suisun Bay, three sites in Central San Francisco Bay, and three sites in South San Francisco Bay during water year 1998. Three types of optical backscatterance sensors that were controlled by an electronic data logger were used to monitor suspended solids. Water samples were collected to calibrate the electrical output of the optical sensors to suspended-solids concentration, and the recorded data were recovered and edited. Suspended-solids concentration data are available from the USGS California District Office.

\section{REFERENCES}

Arthur, J.F., and Ball, M.D., 1979, Factors influencing the entrapment of suspended material in the San Francisco Bay-Delta Estuary, in Conomos, T.J., ed., San Francisco Bay: The urbanized estuary: San Francisco, Pacific Division of the American Association for the Advancement of Science, p. 143-174.

Brown, C.L., and Luoma, S.N., 1995, Use of the euryhaline bivalve Potamocorbula amurensis as a biosentinal species to assess trace metal contamination in San Francisco Bay: Marine Ecology Progress Series, v. 124, p. 129-142.

Buchanan, P.A., and Schoellhamer, D.H., 1995, Summary of suspended-solids concentration data, Central and South San Francisco Bays, California, water years 1992 and 1993: U.S. Geological Survey OpenFile Report 94-543, 15 p.

- 1996, Summary of suspended-solids concentration data, San Francisco Bay, California, water year 1995: U.S. Geological Survey Open-File Report 96-591, 40 p.

_ 1998, Summary of suspended-solids concentration data, San Francisco Bay, California, water year 1996: U.S. Geological Survey Open-File Report 98-175, 59 p.

- 1999, Summary of suspended-solids concentration data, San Francisco Bay, California, water year 1997: U.S. Geological Survey Open-File Report 99-189, 52 p.

Buchanan, P.A., Schoellhamer, D.H., and Sheipline, R.C., 1996, Summary of suspended-solids concentration data, San Francisco Bay, California, water year 1994: U.S. Geological Survey Open-File Report 95-776, $48 \mathrm{p}$.

Carlson, P.R., and McCulloch, D.S., 1974, Aerial observations of suspended-sediment plumes in San Francisco Bay and adjacent Pacific Ocean: U.S. Geological Survey Water-Resources Research, v. 2, no. 5, p. 519-526.

Cheng, R.T., and Gartner, J.W., 1984, Tides, tidal and residual currents in San Francisco Bay, California-Results of measurements, 1979-1980:

U.S. Geological Survey Water Resources Investigations Report 84-4339, 72 p.

Cloern, J.E., 1987, Turbidity as a control on phytoplankton biomass and productivity in estuaries: Continental Shelf Research, v. 7, no. 11/12, p. 1367-1381.

$\ldots, 1996$, Phytoplankton bloom dynamics in coastal ecosystems: a review with some general lessons from sustained investigation of San Francisco Bay, California: Reviews of Geophysics, v. 34, no. 2, p. $127-168$.

Cole, B.E., and Cloern, J.E., 1987, An empirical model for estimating phytoplankton productivity in estuaries: Marine Ecology Progress Series, v. 36, p. 299-305.

Conomos, T.J., and Peterson, D.H., 1977, Suspended-particle transport and circulation in San Francisco Bay, an overview: New York, Academic Press. Estuarine Processes, v. 2, p. 82-97.

D \& A Instrument Company, 1991, OBS-1 \& 3: Suspended solids and turbidity monitor (rev. 3/91): Port Townsend, WA, D \& A Instrument Company Instruction Manual, Part No. OBS-1/3 man, 41 p. 
Domagalski, J.L., and Kuivila, K.M., 1993, Distributions of pesticides and organic contaminants between water and suspended sediment, San Francisco Bay, California: Estuaries, v. 16, no. 3A, p. 416-426.

Downing, J.P., 1983, An optical instrument for monitoring suspended particulates in ocean and laboratory: in OCEANS 1983, San Francisco, California, August 29-September 1, 1983, Proceedings: p. 199-202.

Downing, J.P., Sternburg, R.W., and Lister, C.R.B., 1981, New instrumentation for the investigation of sediment suspension processes in the shallow marine environment: Marine Geology, v. 42, p. 19-34.

Fishman, M.J., and Friedman, L.C., 1989, Methods for determination of inorganic substances in water and fluvial sediments: U.S. Geological Survey Techniques of Water-Resources Investigations, book 5, chap. A1, 545 p.

Flegal, A.R., Rivera-Duarte, I., Ritson, P.I., Scelfo, G.M., Smith, G.J., Gordon, M.R., and Sanudo-Wilhelmy, S.A., 1996, Metal contamination in San Francisco Bay waters: Historic perturbations, contemporary concentrations, and future considerations: San Francisco Bay: The Ecosystem, Hollibaugh, J.T. ed., Pacific Division of the American Association for the Advancement of Science, San Francisco, p. 173-188.

Hammond, D.E., Fuller, C., Harmon, D., Hartman, B., Korosec, M., Miller, L.G., Rea, R., Warren, S., Berelson, W., and Hager, S.W., 1985, Benthic fluxes in San Francisco Bay: Hydrobiologia, v. 129, p. 69-90.

Helsel, D.R., and Hirsch, R.M., 1992, Statistical methods in water resources: Studies in Environmental Science, v.49, Elsevier, New York, 522 p.

Jassby, A.D., and Powell, T.M., 1994, Hydrodynamic influences on interannual chlorophyll variability in an estuary: Upper San Francisco Bay-Delta (California, U.S.A.): Estuarine, Coastal and Shelf Science, v. 39, p. 595-618.

Jennings, B., Schoellhamer, D.H., and Kuivila, K.M., 1997, Optimum sampling strategy for sedimentassociated pesticides in Suisun Bay: Interagency Ecological Program Newsletter, v. 10, no.4, p. 16-20.

Kimmerer, Wim, 1992, An evaluation of existing data in the entrapment zone of the San Francisco Bay Estuary: Tiburon, California, Biosystems Analysis, Inc., Technical Report 33, 49 p.

Kuwabara, J.S., Chang, C.C.Y., Cloern, J.E., Fries, T.L., Davis, J.A., and Luoma, S.N., 1989, Trace metal associations in the water column of South San Francisco Bay, California: Estuarine, Coastal and Shelf Science, v. 28, p. 307-325.

Lacy, J.R., Schoellhamer, D.H., and Burau, J.R., 1996, Suspended-solids flux at a shallow-water site in South San Francisco Bay, California, in Bathala, C.T., ed., North American Water and Environment Congress, Anaheim, Calif., June 23-28, 1996, Proceedings: New York, American Society of Civil Engineers.

Levesque, V.A., and Schoellhamer, D.H., 1995, Summary of sediment resuspension monitoring, Old Tampa Bay and Hillsborough Bay, Florida, 1988-91: U.S. Geological Survey Water-Resources Investigations Report 94-4081, $31 \mathrm{p}$.

Luoma, S.N., 1996, The developing framework of marine ecotoxicology: Pollutants as a variable in marine ecosystems?: Journal of experimental marine biology and ecology, v. 200, p. 29-55.

Luoma, S.N., Cain, D., and Johansson, C., 1985, Temporal fluctuations of silver, copper, and zinc in the bivalve Macoma balthica at five stations in South San Francisco Bay: Hydrobiologia, v. 129, p. 109-120.

Oltmann, R.N., Schoellhamer, D.H., and Dinehart, R.L., 1999, Sediment inflow to the Sacramento-San Joaquin Delta and the San Francisco Bay: Interagency Ecological Program Newsletter, v. 12, no. 1, p. 30-33.

Peterson, D.H., Conomos, T.J., Broenkow, W.W., and Doherty, P.C., 1975, Location of the non-tidal current null zone in northern San Francisco Bay: Estuarine and Coastal Marine Science, v. 3, p. 1-11.

Porterfield, George, 1980, Sediment transport of streams tributary to San Francisco, San Pablo, and Suisun Bays, California, 1909-1966: U.S. Geological Survey Water-Resources Investigations Report 80-64, 91 p.

Powell, T.M., Cloern, J.E., and Huzzey, L.M., 1989, Spatial and temporal variability in South San Francisco Bay (U.S.A.). I. Horizontal distributions of salinity, suspended sediments, and phytoplankton biomass and productivity: Estuarine, Coastal and Shelf Science, v. 28, p. 583-597.

Ruhl, C.A., and Schoellhamer, D.H., 1999, Time series of suspended-solids concentration in Honker Bay during water year 1997: 1997 Annual Report of the Regional Monitoring Program for Trace Substances, www.sfei.org/rmp/1997/c0304.htm. 
Schoellhamer, D.H., 1996, Factors affecting suspended-solids concentrations in South San Francisco Bay, California: Journal of Geophysical Research, v. 101, no. C5, p. 12087-12095.

- 1997, Time series of trace-element concentrations calculated from the series of suspended-solids concentrations and RMP water samples: 1995 Annual Report of the Regional Monitoring Program for Trace Substances, p. 53-55.

Schoellhamer, D.H., and Burau, J.R., 1998, Summary of findings about circulation and the estuarine turbidity maximum in Suisun Bay, California: U.S. Geological Survey Fact Sheet FS-047-98, 6 p.

Siegel, A.R., 1982, Robust regression using repeated medians: Biometrika, v.69, p. 242-244.

Smith, L.H., 1987, A review of circulation and mixing studies of San Francisco Bay, California: U.S. Geological Survey Circular 1015, 38 p.

Tobin, Ann, Schoellhamer, D.H., and Burau, J.R., 1995, Suspended-solids flux in Suisun Bay, California, in First International Conference of Water Resources Engineering, San Antonio Texas, August 14-18, 1995, Proceedings: New York, American Society of Civil Engineers, p. 1511-1515.

U.S. Environmental Protection Agency, 1992, State of the estuary: Dredging and waterway modification: U.S. Environmental Protection Agency San Francisco Estuary Project, chap. 8, p. 191-215. 